\title{
Cardiovascular Effects of Modulators of Soluble Guanylyl Cyclase Activity
}

\author{
*Markus Hoenicka, PhD; Christof Schmid, MD \\ University Hospital of Regensburg, Department of Cardiothoracic \\ Surgery, Regensburg, Germany
}

*Corresponding Author: University Hospital of Regensburg, Department of Cardiothoracic Surgery, Franz-Josef-Strauss-Allee 11, 93053 Regensburg, Germany.

Phone: ++49-941-944-9901

Fax: ++49-941-944-9802

Email: markus.hoenicka@klinik.uni-regensburg.de

Keywords: cyclic guanosine monophosphate, soluble guanylyl cyclase, nitric oxide, carbon monoxide, cardiovascular diseases, atherosclerosis, hypertension, shock

Publication Note:

Cardiovasc Hematol Agents Med Chem. 2008 Oct;6(4):287-301. Review.PMID: 18855642

http://www.bentham.org/cmccha/index.htm 


\section{Abstract}

Soluble guanylyl cyclase (sGC) is one of the key enzymes of the nitric-oxide (NO)/cyclic 3',5'-guanosine monophosphate (cGMP) pathway. Located in virtually all mammalian cells, it controls the vessel tone, smooth muscle cell growth, platelet aggregation, and leukocyte adhesion. In vivo sGC activity is mainly regulated by NO which in turn is released from L-arginine by nitric oxide synthases. One of the main diseases of the cardiovascular system, endothelial dysfunction, leads to a diminished NO synthesis and thus increases vessel tone as well as the risk of thrombosis. The predominant therapeutic approach to this condition is a NO replacement therapy, as exemplified by organic nitrates, molsidomin, and other NO releasing substances. Recent advances in drug discovery provided a variety of other approaches to activate sGC, which may help to circumvent both the tolerance problem and some non-specific actions associated with NO donor drugs. Substances like BAY 41-2272 stimulate sGC in a heme-dependent fashion and synergize with $\mathrm{NO}$, allowing to enhance the effects both of endogenous NO and of exogenous NO donors. On the other hand, heme-independent activators like BAY 58-2667 allow to activate $\mathrm{sGC}$ even if it is rendered unresponsive to NO due to oxidative stress or heme loss. Furthermore, a few substances have been described as specific inhibitors of sGC that allow to alleviate the effects of excess NO production as seen in septic shock. This review discusses the cardiovascular effects of heme-dependent and heme-independent activators as well as of inhibitors of sGC. 


\section{INTRODUCTION}

The nitric oxide (NO)/cyclic guanosine monophosphate (cGMP) signal transduction pathway is a common mechanism which controls the blood vessel tone [1], the growth rate of vascular smooth muscle cells_[2], the aggregation of thrombocytes_[3], and the adhesion of leucocytes to the vessel wall_4]. NO activates soluble guanylyl cyclase (sGC) which leads to an increased synthesis of cGMP. Carbon monoxide $(\mathrm{CO})$ is another gaseous signalling molecule which at least partially acts through the same heme protein. $\mathrm{CO}$ seems to play an important role in the prevention of atherosclerotic lesions [5], protects against ischemia/reperfusion injury in the heart_[6,7], attenuates neointima formation after balloon angioplasty [5,8], inhibits apoptosis of vascular cells_[9,10], regulates the blood vessel tone in some vascular beds [11], and has an antiaggregatory effect on platelets_[12]. As with all regulatory mechanisms in higher organisms, there is a well-tuned balance between the cGMP-mediated transduction systems and other signal transduction pathways that affect the cardiovascular system. However, pathological conditions may cause a reduced bioavailability of $\mathrm{NO}$, an excess production of NO, or a reduced effect of NO. Along the same lines, a reduced or increased production of $\mathrm{CO}$ accompanies a variety of diseases. This review summarizes the biochemical background as well as the recent advances in the development of sGC-targeted therapies of cardiovascular diseases.

\section{SIGNAL TRANSDUCTION BY SOLUBLE GUANYLYL CYCLASE AND CYCLIC GUANOSINE MONOPHOSPHATE}

The NO/cGMP system had been the target of cardiovascular drugs long before the underlying mechanisms began to emerge. As early as 
1867 amyl nitrite was administered to relieve the symptoms of angina pectoris [13]. Glyceryl trinitrate (GTN), a substance which is still a mainstay of antianginal therapy today_[14,15], was found to be even more effective only a few years later_[16]. However, it took almost a century until the increased synthesis of cGMP by soluble guanylyl cyclase (sGC) upon exposure to nitric oxide and GTN was established [17,18] and until the action of GTN was attributed to the release of $\mathrm{NO}$ [19]. This was seen as an exciting pharmacological principle back then, but the seminal work of Furchgott et al. [20] who first described the release from the endothelium of a relaxing factor (EDRF) after acetylcholine administration, and the identification of this factor as NO or a closely related species_[21-23] showed that a variety of cells are capable of generating NO themselves. Only four years later the first isoenzyme of a family of enzymes responsible for generating NO (nitric oxide synthase, NOS) was purified [24]. Nitric oxide is synthesized by NOS, of which three isoenzymes are known (Table 1). A fourth isoenzyme, called mtNOS, has been isolated from mitochondria. This isoform seems to be involved in mediating oxidative injury in ischemia/reperfusion_[25], but its role in the healthy vascular system, if any, is currently unclear_[26]. The structurally related extramitochondrial enzymes differ in their tissue distribution as well as in their mechanisms of regulation [27,28]. Of these, the isoforms NOS-2 and NOS-3 are involved in a variety of vasculopathies. NOS-3 is constitutively expressed in endothelial cells and in a variety of blood cells like platelets. Its activity is strongly dependent on intracellular $\mathrm{Ca}^{2+}$ which may change on a small timescale. Both its level of expression and its activity are regulated by mechanical as well as by humoral factors_[29,30]. The main purpose of this isoenzyme is to link hemodynamic stimuli (shear stress, distension) and hormonal signals to the synthesis of NO 
which in turn acts on the smooth muscle layer, causing a relaxation, as well as on blood cells, inhibiting aggregation and/or adhesion_[31]. On the other hand, NOS-2 is mainly a mediator of unspecific host defense [32], which is upregulated in macrophages, monocytes, and other cells in response to stimuli like interferon $\gamma$ (IFN- $\gamma)$, tumor necrosis factor a (TNF-a), interleukin 1, and lipopolysaccharide (LPS)_[33,34]. Once expressed at an elevated level, NOS-2 produces large quantities of NO for sustained periods of time. Therefore, even though NOS-2 may contribute to the basal level of NO production in healthy vessels, it plays a major role in the cardiovascular system mainly by causing the hypotensive and vasoplegic state characteristic for circulatory shock.

The main cellular target of NO is sGC. The structure and function of this enzyme will be dealt with in more detail in the following section. The association of NO with the heme moiety of sGC increases the rate of synthesis of cGMP from guanosine triphosphate (GTP) up to 200-fold, leading to an increase in the intracellular steady-state concentration of this second messenger up to approx. 30-fold_[17]. cGMP in turn binds to two different binding motifs in a variety of effector proteins. The first one is shared by protein kinase $G(P K G)$, cAMP-dependent protein kinase (PKA), and cyclic nucleotide-gated cation channels. The other one is found in cGMP-regulated phosphodiesterases (PDE) [35]. cGMP binding affects the activity of the target enzymes and thus causes the cellular effects of an elevated cGMP level. Effects of NO and of NO-releasing compounds which are not mediated by cGMP have been reviewed elsewhere_[36].

Like any other well-designed signalling system, the cGMP levels are controlled both by the rate of synthesis and by the rate of degradation. The latter is influenced mainly by various isoforms of PDE, which hydrolyze the second messenger to the inactive guanosine 
monophosphate (GMP) [37,38], and by extrusion into the extracellular space [39].

We now know that $\mathrm{NO}$ is not the only gaseous transmitter in the cardiovascular system. $\mathrm{CO}$ is another diatomic gas with strikingly similar properties compared to NO, with the exception that it is not a radical (we will not cover hydrogen sulfide as the third "gasotransmitter" [40] here as its cardiovascular actions do not involve an interaction with sGC_[41-43]). $\mathrm{CO}$ is generated from heme, the ubiquitous cofactor of hemoproteins like the cytochromes and the oxygen carrier hemoglobin. The synthesis of heme is a sequence of coordinated reactions that occur partly in the cytosol, whereas the final assembly of the ring structure and the insertion of the central iron occurs in mitochondria [44]. The enzymes responsible for the oxidative release of $\mathrm{CO}$ from heme are isoenzymes of the heme oxygenase (HO) family of enzymes and are located in microsomes. This rate-limiting step in the degradation of heme yields equimolar amounts of biliverdin IXa, CO, and ferrous iron. Biliverdin IXa is further transformed by biliverdin reductase to the potent antioxidant bilirubin, whereas the free iron has to be sequestered immediately by ferritin to avoid the catalysis of reactions leading to reactive oxygen species_[45-47]. $\mathrm{CO}$ is derived from the a-methene carbon of heme. Its removal causes the ring structure to open. $\mathrm{CO}$ has initially been viewed as a byproduct of a purely catabolic mechanism to break down heme_48]. However, the discovery of the isoforms HO-2 [49] and HO-3 [50] in addition to the one originally identified in rat liver and spleen (now called HO-1) sparked further interest in possible non-catabolic roles of the heme degradation (see also Table 1). HO- 1 is an inducible enzyme, whereas HO-2 is expressed constitutively. The existence of HO-3 as a separate gene has later been drawn into question as the transcripts are likely to be alternatively 
processed transcripts of the HO-2 gene [51]. HO-1 and HO-2 are both expressed in the brain (among other tissues) with a very distinct distribution between brain regions and individual cell types [52]. Especially the hippocampus expresses high levels of HO isoenzymes as well as sGC, but contains only a small population of neurons expressing NOS_[53]. This finding strongly suggested a role of $\mathrm{CO}$ as a signalling molecule in at least some regions of the brain, a conclusion that was later extended to other tissues as well.

The cardiovascular system is capable of generating substantial amounts $\mathrm{CO}$, due to the abundance of the substrate heme and to a high level of HO activity_[54,55]. Heme oxygenase activity is found both in smooth muscle cells_[56,57] and in endothelial cells_[58]. There are several targets for the signalling molecule $\mathrm{CO}$ in the vasculature. One of them is $\mathrm{SGC}$, in a striking resemblance to $\mathrm{NO}$, with further details given in the next section. Other known targets are large-conductance potassium channels_[59-61], which act as oxygen sensors_[62], and cytochrome P450 enzymes [63].

\begin{tabular}{|l|l|l|l|}
\hline isoform & alternative names & regulation & tissue distribution \\
\hline NOS-1 & nNOS (neuronal) & $\begin{array}{l}\mathrm{Ca}^{2+}, \text { HSP90, phos- } \\
\text { phorylation }\end{array}$ & $\begin{array}{l}\text { central and peripheral } \\
\text { neurons, nonadrenergic } \\
\text { and noncholinergic neu- } \\
\text { rons, islets, endome- } \\
\text { trium, skeletal muscle }\end{array}$ \\
\hline NOS-2 & iNOS (inducible) & $\begin{array}{l}\left(\mathrm{Ca}^{2+}\right), \text { LPS, cyto- } \\
\mathrm{kines}^{2}, \text { glucocorticoids }\end{array}$ & $\begin{array}{l}\text { macrophages, liver, } \\
\text { smooth muscle, endo- } \\
\text { thelium, heart }\end{array}$ \\
\hline NOS-3 & eNOS (endothelial) & $\begin{array}{l}\mathrm{Ca}^{2+}, \text { HSP90, myris- } \\
\text { toylation, palmitoyla- } \\
\text { tion, phosphorylation }\end{array}$ & $\begin{array}{l}\text { endothelium, brain, } \\
\text { heart }\end{array}$ \\
\hline
\end{tabular}




\begin{tabular}{|l|l|l|l|}
\hline HO-1 & HSP32 & $\begin{array}{l}\text { heat, hypoxia, oxidat- } \\
\text { ive stress }\end{array}$ & $\begin{array}{l}\text { heart, liver, spleen, kid- } \\
\text { ney, brain }\end{array}$ \\
\hline HO-2 & & $\begin{array}{l}\text { hypoxia, redox sta- } \\
\text { tus, adrenal glucocor- } \\
\text { ticoids }\end{array}$ & $\begin{array}{l}\text { brain, liver, endotheli- } \\
\text { um, testis }\end{array}$ \\
\hline HO-3 & HO-3a/HO-3b & & \\
\hline
\end{tabular}

Table 1: Isoforms of nitric oxide synthase (NOS) and of heme oxygenase (HO). The alternative NOS names refer to the tissue from which the isoform was first isolated (nNOS, eNOS) or to the most obvious difference to the other isoforms (iNOS) and are given solely for reference to older literature (compiled from [27], [28], [51], [52], [234]).

\section{STRUCTURE AND FUNCTION OF SOLUBLE GUANYLYL CYCLASE}

In order to understand the pharmaceutical approaches targeted at sGC, a thorough understanding of the structure and function of this enzyme is helpful. This section attempts to summarize our current knowledge about the structure of sGC as well as of the mechanisms available to activate and to inhibit this enzyme. As the focus is on the molecular mechanisms, we'll cover only "archetypical" agents in this section. A full coverage of the substances in use for therapeutical or experimental purposes will be provided in a subsequent section.

sGC (GTP pyrophospate-lyase, EC 4.6.1.2) is a member of the family of nucleotide cyclizing enzymes, along with adenylyl cyclase and particulate guanylyl cyclases_[64]. All of these enzymes share a strong homology of the catalytic domains, as each of these enzymes catalyzes the same cyclic 3'-5' phosphorylation of either adenosine triphosphate (ATP) or guanosine triphosphate (GTP). Mammalian 
adenylate cyclases and particulate guanylyl cyclases are transmembrane proteins which are activated by the $\mathrm{G}$ protein a subunit and by natriuretic peptides, respectively. sGC, on the other hand, is a soluble dimeric enzyme which consists of an a subunit and a somewhat smaller $\beta$ subunit_65]. There are two variants of each subunit known in humans_[66], although only the $a_{1} / \beta_{1}$ (the predominant form) and the $a_{2} / \beta_{1}$ (mainly found in the brain) heterodimers were confirmed in vivo[67]. The $a_{1} / \beta_{1}$ isoform was shown to be responsible for most but not all of the sGC-mediated vasorelaxation in knockout mice [68]. Each heterodimer contains a single heme moiety [69,70] whose ferrous iron is coordinated by four nitrogens of the porphyrinic ring and another nitrogen provided by the histidine residue His-105 of the $\beta$-subunit as an axial ligand [71]. The heme is essential for the activation of the enzyme by nitric oxide [72,73] and by the closely related nitroxyl anion $\mathrm{NO}^{-}$[74]. In the basal state, this heme iron is in a pentacoordinate high-spin state_[75]. Binding of NO on the distal side results in an intermediate hexacoordinate complex, which is transformed in a rate-limiting step into a pentacoordinate complex by breaking the iron-histidine bond [76,77]. An analysis of a bacterial cytochrome c' with a heme binding domain strikingly similar to that of sGC suggests that the rate-limiting step actually may involve a second NO molecule, which replaces the histidine as the axial ligand on the proximal side, causing the initially bound NO on the distal side to leave[78]. The formation of the ferrous nitrosyl-heme complex increases the activity of sGC approx. 200-fold in the presence of $\mathrm{Mg}^{2+}$-GTP as substrate. The sensitivity of the enzyme towards NO activation is further modulated by a $\mathrm{Ca}^{2+}$ dependent mechanism which causes sGC to associate with the cell 
membrane, especially in caveolae close to NOS_[79-81].

$\mathrm{CO}$ is also known to activate $\mathrm{sGC}[12,82]$ as it can bind to the heme moiety of sGC in a similar fashion as $\mathrm{NO}[70,83,75]$. There has been some debate as to whether $\mathrm{CO}$ binding to the heme moiety alone is sufficient to activate the enzyme. Early reports failed to find a significant activation by $\mathrm{CO}[83,84]$, while it is now commonly accepted that there is an up to 15 -fold activation of cGMP synthesis upon CO binding when the experiments are performed in the absence of environmental NO[69]. Spectral studies revealed that $\mathrm{CO}$ also binds to the heme on the distal side, but does not cause the iron-histidine bond to break [85]. This leaves the iron-CO complex in a hexacoordinate state, which partially explains the different activation of sGC by $\mathrm{NO}$ and $\mathrm{CO}$. A thorough structural analysis of the hemebinding domain of $\mathrm{sGC}$ revealed that both $\mathrm{NO}$ and $\mathrm{CO}$ binding causes the heme to pivot, but to a different degree [77].

The dissociation of the heme ligand offered additional insight in the activation mechanism. An analysis of the dissociation of NO allowed to distinguish two pentacoordinate heme-nitrosyl complexes which are in a slow equilibrium. Only one of these states ("open") has a high activity, whereas the other one ("closed") results in a slow cGMP synthesis. The "open" state rapidly equilibrates with a hexacoordinate form that can eventually release the NO to return to the pentacoordinate heme-histidin complex which displays basal activity $[86,87]$.

Several sGC inhibitors have been described so far, among them superoxide_[82], methylene blue and 6-anilino,5,8-quinolinedione (LY83583)_[88], 1H-[1,2,4]oxadiazolo[4,3-a]quinoxalin-1-one (ODQ) [89,90], and 4H-8-bromo-1,2,4-oxadiazolo(3,4-d)benz(b)(1,4)oxazin1-one (NS 2028) [91]. The common mechanism of these inhibitors appears to be the oxidation of the ferrous heme iron to ferric iron 
either directly or via the generation of reactive oxygen species, leaving the iron incapable of binding $\mathrm{NO}$ or CO. Enzyme activation by NO can usually be restored by reducing the heme iron with dithionite [92]. So, strictly speaking, these substances are not classic enzyme inhibitors but they rather prevent the activation of the enzyme by heme ligands, which still allows for a basal cGMP synthesis to occur. The inhibiting effect of $\mathrm{N}$-methylhydroxylamine is competitive to NO donors like sodium nitroprusside (SNP) which suggest either an interaction with heme or a NO scavenging effect [93].

In 1994 a new class of sGC modulators was discovered with the description of the antithrombotic properties of 3-(5'-hydroxymethyl-2'furyl)-1-benzyl indazole (YC-1) in rabbits and mice [94]. It was later established that $\mathrm{YC}-1$ can stimulate $\mathrm{SGC}$ in the absence of NO [95] and to a small degree even in the absence of heme [96], but its action is greatly enhanced if the reduced heme is present_[97]. However, spectroscopic studies indicate that $\mathrm{YC}-1$ is unlikely to bind to the heme moiety $[69,98]$. Moreover, the activation by $\mathrm{YC}-1$ is synergistic with NO, allowing an enzyme activation up to 800fold, and can be blocked by ODQ_[69]. Even more intriguing, YC-1 allows CO to activate sGC to a degree similar to NO $[69,99]$. There are conflicting data about the exact binding site and the mechanism of action of YC-1. Photoaffinity labelling with BAY 51-9491, a substance structurally related to $\mathrm{YC}-1$, suggested an interaction of $\mathrm{YC}-1$ with the cysteine residues 238 and 243 of the regulatory domain of the $a_{1}$ subunit $[100]$. However, a homodimer consisting of two truncated $\beta_{1}$ subunits still interacted with $\mathrm{YC}-1$, suggesting a binding site in the $\mathrm{N}$-terminal region of the $\beta$ subunit which comprises the corresponding regulatory domain of that subunit_[101]. On the other hand, point mutations in the catalytic domains of the subunits resulted in 
an enzyme unresponsive to YC-1_[102]. It is probably impossible to reconcile these data without further knowledge of the 3D structure which is still unknown. One working hypothesis is the insertion of YC-1 into the hydrophobic interface between the regulatory domains of both subunits. This seems feasible as the furane and indazole rings of $\mathrm{YC}-1$ are coplanar, whereas only the ring of the benzyl residue lies perpendicular to the former [103]. As both the binding of $\mathrm{YC}-1$ and the alteration of the heme pocket elicited by NO or $\mathrm{CO}$ binding have to be transmitted by structural changes to the catalytic domains, a reverse effect of mutations in these areas on the binding of YC-1 is not unlikely. The discovery of further stimulators of sGC, which will be described in detail shortly, was greatly simplified by sGC overexpressing cell lines suitable as readout systems in high throughput screening assays_[104], and their characterization was facilitated by novel methods to express and purify milligram quantities of recombinant sGC [69,105].

Several investigations attempted to find a molecular explanation for the synergistic effect of $\mathrm{YC}-1$ and heme ligands. Two mechanisms are likely to contribute to the observed effect. First, YC-1 appears to weaken the His-iron bond in the hexacoordinate NO and $\mathrm{CO}$ bound states, which would reasonably explain the high sGC stimulation by $\mathrm{CO}$ in the presence of $\mathrm{YC}-1[106]$. Second, it is now generally accepted that $\mathrm{YC}-1$ decelerates the dissociation of the heme ligand $[107,108,85,109,102]$ and thus increases the likelyhood that the enzyme is in the pentacoordinate "open" state [86]. In other words, YC1 is a moderately effective stimulator of sGC in the absence of a heme ligand, but a strong deactivation inhibitor of $\mathrm{NO}$ or $\mathrm{CO}$ activated sGC.

Before NO was identified as an endogenous sGC modulator, heme analogs were discussed as a regulatory mechanism_[76]. Protopor- 
phyrin IX (a heme lacking the central iron) and hematoporphyrin IX (a protoporphyrin IX with slightly modified side chains) were shown to activate heme-free sGC, whereas ferriprotoporphyrin IX (heme with a ferric iron) acted as a potent inhibitor [84,110]. BAY 58-2667 was the first activator not based on a porphyrin structure which appears to act by binding to the heme binding domain of sGC [111], thus displacing the heme and freeing the His-105. A space-filling electronic model of BAY 58-2667 exhibited a striking similarity with heme in terms of the 3D-structure, the charge distribution, and the position of residues critical for attaching to the binding domain [112]. The substance was shown to interact with the invariant amino acids Tyr-135 and Arg-139 of the $\beta$ subunit. In contrast to NO, CO, or YC-1, BAY 58-2667 has the unique ability to activate $\mathrm{sGC}$ if the heme is oxidized or if it is removed entirely from the enzyme.

Taken together, therapeutic interventions have the following options to activate SGC and thus increase cGMP synthesis: (1) deliver, increase the synthesis of, or increase the bioavailabilty of NO, (2) deliver or increase the synthesis of $\mathrm{CO}$, (3) stabilize the NO or $\mathrm{CO}$ adduct, or (4) replace the heme with something that mimicks the heme-nitrosyl complex. To date, there is no therapeutically useful way to block the basal activity of the enzyme, but oxidizing the heme prevents the activation of SGC by heme ligands which is more than sufficient to achieve an overall reduction of cGMP synthesis. The mechanisms of modulating sGC activity are depicted in the context of the NO/cGMP and CO/cGMP signal transduction pathways in Fig. (1). 


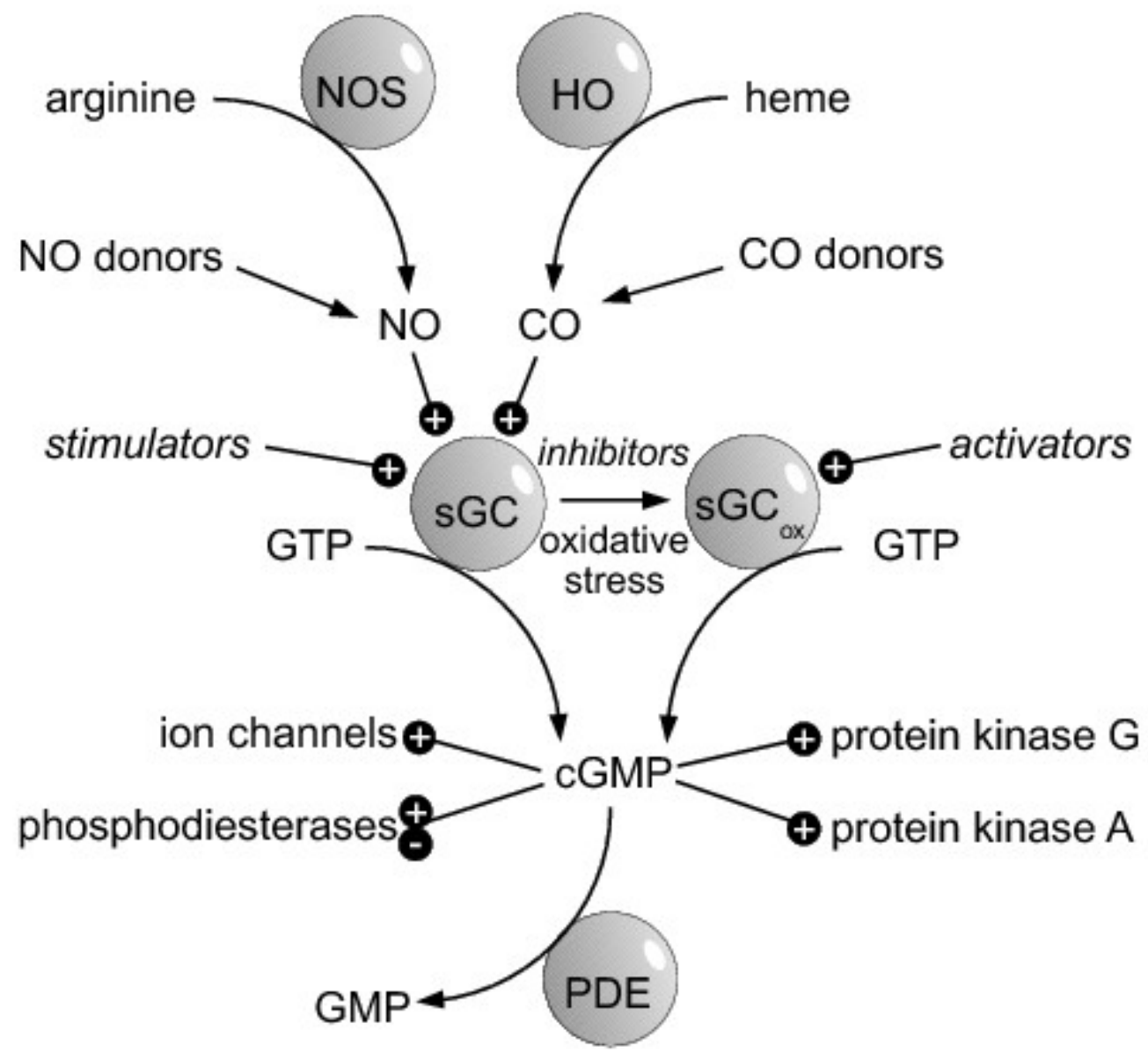

Fig. 1: Schematic representation of the signal transduction mediated by sGC. NO, nitric oxide; CO, carbon monoxide; NOS, nitric oxide synthase; HO, heme oxygenase; sGC, soluble guanylyl cyclase; $\mathrm{sGC}_{\mathrm{ox}}$, heme-oxidized soluble guanylyl cyclase; GTP, guanosine triphosphate; cGMP, cyclic guanosine monophosphate; GMP, guanosine monophosphate; PDE, phosphodiesterase. "stimulators", "activators", and "inhibitors" denote the classes of heme-dependent activators, heme-independent activators, and oxidants, respectively, which modulate sGC activity. 


\section{PATHOLOGIES RELATED TO INAPPROPRIATE SYNTHESIS OR EFFECT OF NO AND OF CO}

As noted previously, cGMP-mediated signalling plays a crucial role in a variety of aspects of the cardiovascular system. Therefore it is not suprising to find a number of pathologies related to reduced or excess production of $\mathrm{NO}$ or $\mathrm{CO}$, or to a reduced effect of these gaseous messengers. Before moving on to potential therapeutic agents that target sGC, we'll briefly review the current knowledge about some of these diseases with a focus on the role of the cGMP signalling pathways in the etiology or in the symptoms.

\section{Atherosclerosis and intimal hyperplasia}

The excess proliferation of smooth muscle cells is one of the symptoms of atherosclerosis and, somewhat ironically, also a potential consequence of therapeutic interventions intended to cure these symptoms, like balloon angioplasty, stenting, and coronary artery bypass grafting. Atherosclerosis is a progressive and chronic inflammatory response of the vasculature and is the main cause of coronary artery disease [113]. Atherosclerotic lesions are intimal thickenings which consist of cells, including blood-bourne immune cells, vascular smooth muscle cells, and endothelial cells, as well as an accumulation of extracellular matrix, lipids, and debris. The chronic consequences of this disease are closely related to the endothelial dysfunction that is an early marker of this disease [114], and which impairs the release of endogenous vasodilating and antithrombotic substances like NO and prostacyclin in the affected areas_[115]. Acute consequences include the complete restriction of blood flow as seen in an acute myocardial infarction, either as a consequence of an excessive plaque size, or of a thrombus formation due to plaque rupture or endothelial erosion. The proliferation of vascular smooth 
muscle cells (VSMC) has been recognized as one of the key events of the development of atherosclerotic lesions_[116]. It is generally assumed that cGMP, and thus all sGC-activating mechanisms, have an antiproliferative effect on smooth muscle cells, which ascribes a key role to an intact NO-generating endothelium in preventing an excessive VSMC proliferation. However, this view has been challenged by experiments using cGMP-dependent protein kinase I knockouts which revealed both pro- and antiproliferative mechanisms triggered by cGMP_[117]. Furthermore, increasing NOS-3 expression to increase cGMP levels has not always provided beneficial results in terms of the progression of the disease_[118]. These results notwithstanding, there is ample evidence for an antiatherogenic role of $\mathrm{NO}[119]$ and increasing evidence that $\mathrm{CO}$ may play a similar role $[5,8,120,121]$.

The development of percutaneous treatments of stenoses using ballon angioplasty or stenting has been a major progress in the treatment of coronary artery disease. However, an estimated $30 \%-50 \%$ of all patients undergoing simple angioplasty and $10 \%-30 \%$ of all patients receiving a stent suffer from restenosis [122,123]. This should not be viewed as a recurrence of the underlying vascular disorder, but as a consequence of the intervention itself [124,125]. Coronary artery bypass grafting with autologous vessels is still the treatment of choice, especially for multivessel coronary artery disease $[126,122]$. However, this treatment may cause a similar neointimal formation as well. Differences in the diameter or a compliance mismatch between the graft and the diseased vessel, as well as flow disturbances at the anastomoses may induce neointima proliferation $[127,128]$. Moreover, if the saphenous vein has to be used as a graft, as opposed to one of the arteries, the adaptation of the venous vessel to the arterial circulation induces "vein graft disease" with in- 
creased neointima formation [129-131]. Both $\mathrm{NO}[125]$ and $\mathrm{CO}[132]$ supplementation have been shown to inhibit neointima formation after endothelial injury.

\section{Arterial hypertension}

Arterial hypertension is characterized by a chronically elevated blood pressure. The majority of these cases can be classified as essential hypertension as there is no apparent medical cause. Treatment is usually symptomatic by blood-pressure lowering agents. Several animal models were developed to investigate arterial hypertension, with the spontaneously hypertensive rat (SHR) being the best known. This model showed that hypertension is associated with an impairment of endothelium-dependent relaxation and lower cGMP contents, suggesting an involvement of the NO/cGMP system $[133,134]$. The following major mechanisms contribute to the reduced cGMP synthesis: in the aorta of SHR the release of NO is essentially unaltered[135], but its bioavailability and its effect are decreased due to an excess of reactive oxygen species_[136-139]. There are no major changes in the expression of NOS, whereas the expression of sGC and other cGMP-regulated proteins is attenuated_[140142], suggesting a smooth muscle layer dysfunction secondary to the endothelial dysfunction.

In young SHR a decreased expression of HO-1 and of SGC was shown, indicating an impairment of the CO/cGMP system in addition to the NO/cGMP system [143]. Surprisingly, counterregulatory mechanisms lead to a normalized cGMP synthesis in response to CO. However, the signal transduction downstream of cGMP are apparently attenuated at this stage, leaving the overall CO/cGMP signal transduction in a dysfunctional state [144]. Interestingly, transgenic mice that overexpress HO-1 showed an elevated rather than a 
reduced blood pressure, arguing against a vasodilatory role of $\mathrm{CO}$ in the vasculature. sGC expression was not reduced, but the sGC-mediated responses to exogenous NO were reduced. These responses could be restored by administering the $\mathrm{HO}$ inhibitor tin protoporphyrin IX. Apparently the excess $\mathrm{CO}$ released by HO competes with NO for the sGC heme, but causes a far less cGMP production when bound [145].

\section{Pulmonary arterial hypertension}

In contrast to arterial hypertension which usually manifests itself systemically, the blood pressure elevation in pulmonary hypertension is restricted to the pulmonary circulation and is accompanied by vascular remodeling of the lung and by right ventricular hypertrophy. Although the etiology of this disease differs from arterial hypertension, the regulatory mechanisms of the endothelium and the consequences of endothelial dysfunction are strikingly similar_[146149]. There is apparently no downregulation of NOS, but in addition to a reduced bioavailability of $\mathrm{NO}$ due to oxidative stress an increased level of the endogenous NOS inhibitor asymmetric dimethylarginine (ADMA) may play a crucial role[150]. ADMA does not only reduce NO synthesis, but it also uncouples the enzyme, allowing electron transfer to oxygen instead of to arginine which ultimately causes oxidative and nitrosative stress_[151]. Other contributing factors to the uncoupling may be a reduced availability of the substrate arginine due to an excess of arginase [152] and a lack of the essential NOS cofactor tetrahydrobiopterin [153].

Inhaled NO was first used in 1991 to reduce the pulmonary vascular resistance [154]. Due to the mainly local effects of the inhaled gas in the well-ventilated areas of the lung there were no systemic cardiovascular effects, in contrast to an equieffective i.v. dose of the 
vasodilator prostacyclin. Alternatively, NO-releasing agents can be administered as aerosols to achieve a similar local effect [155].

A related syndrome, though again of a different etiology, is pulmonary hypertension of the newborn. The pulmonary circulation undergoes a remarkable change during birth in order to allow the newborn to meet her oxygen needs through the lung instead of through the placental circulation. The pulmonary vascular resistance has to fall within minutes in response to various stimuli during birth [156]. Failure to do so is referred to as persistent pulmonary hypertension of the newborn (PPHN) and may lead to severe hypoxia and neurological disorders. VEGF apparently plays a major role in the onset of PPHN as it experimentally causes an NO-mediated vasodilation but appears to be suppressed in PPHN_[157-159]. Just as with other forms of hypertension, NOS uncoupling also seems to be involved [160] although a recent report indicates that uncoupling postnatally creates reactive oxygen species which act as an endothelium-derived hyperpolarizing factor (EDHF) and thus fulfill a regulatory role in the pulmonary circulation of healthy subjects as well[161].

\section{Congestive heart failure}

Congestive heart failure $(\mathrm{CHF})$ is characterized by an increased peripheral vascular resistance, which in turn causes an increased afterload of the heart. CHF is associated with endothelial dysfunction, either as a cause or as a consequence. In this setting, a decreased expression of NOS in the vasculature may cause an insufficient NO synthesis, although a recent study failed to find evidence for this [162]. Instead, an increased level of the endogenous NOS inhibitor ADMA appears to be present in CHF patients [163]. Oxidative stress, partly due to uncoupling of NOS_[164], further decreases the bioavailability of NO. Unfortunately, many CHF patients do not re- 
spond well to a NO replacement therapy with organic nitrates as they show an early onset of nitrate tolerance[165]. One likely reason for this phenomenon is a shift of the equilibrium of ferrous towards ferric heme in sGC due to the increased oxidative stress.

\section{Cardiac myopathy}

A variety of vascular disorders cause a hypertrophy of the heart, or of parts of the heart, in response to increased pulmonary or systemic vascular resistance, or as a consequence of myocardial infarction due to coronary artery disease. There appears to be a compensatory upregulation of NOS-2 in response to a decreased expression and activity of NOS-3 in cardiac tissue in ischemic cardiomyopathy $[166,167]$. The NO/cGMP system is seen as an important regulatory mechanism to prevent hypertrophy [168].

\section{Thrombosis}

Increasing the synthesis of cGMP by platelet sGC through NO formation is one of the mechanisms that an intact endothelium employs to prevent the aggregation of platelets and a subsequent thrombus formation, as reviewed in [169] and in_[170]. See also_[171] for a full list of molecules released by the endothelium which affect platelet function. Platelets are also known to synthesize NO themselves. As mentioned above, the endothelial NO synthesis is tightly regulated by shear stress. Therefore thrombus formation is likely to occur when the blood flow is impaired, e.g. in varicose veins, or if the endothelial production of antithrombotic substances ceases due to endothelial dysfunction. Plaque rupture in an atherosclerotic coronary artery may induce a thrombus and thus cause unstable angina [172] or even acute myocardial infarction [173]. NO donors display antithrombotic effects ex vivo[3] and may thus contribute to prevent thrombosis. 


\section{Circulatory shock}

Shock is characterized by a vasoplegic and hypotensive state which leads to a malperfusion and thus a lack of oxygen. This may ultimately cause a dysfunction of vital organs like the brain, kidney, or liver. Several types of shock are distinguished based on the etiology: cardiogenic shock (myocardial infarction), hemorrhagic shock (fluid or blood loss), septic shock (severe infection), and anaphylactic shock (severe allergic reaction)_[174]. One of the main vasodilators whose levels are increased during shock is NO. However, the origin of NO is still a matter of debate. Polymorphonuclear leucocytes from patients with sepsis syndrome display an increased NOS activity [175] which is mainly due to an increased NOS-2 expression [176]. On the other hand, an analysis in a mouse shock model revealed that the NO production during septic shock depends on parenchymal cells in the liver, kidney, and gut rather than on hematopoietic cells_[177]. The expression of NOS-2 is also increased in the myocardium during sepsis_[178]. Although blocking the NO release is a tempting strategy to overcome the hypotension associated with shock, early attempts have shown a decrease in cardiac output [179] as well as an increased mortality in an animal model_[180]. This is in part due to a paradox protective effect of NO, e.g. on the perfusion of the kidney [174]. An involvement of heme oxygenase in the vascular dysfunction during shock is also discussed, as CO appears to inhibit flow-induced relaxation by inhibiting NOS and by competing with $\mathrm{NO}$ as a heme ligand of $\mathrm{sGC}[181]$.

\section{SOLUBLE GUANYLYL CYCLASE STIMULATORS AND ACTIVATORS}

The description of the mechanisms of activation of sGC outlined the available strategies to elevate intracellular cGMP levels by com- 
pounds that directly interact with $\mathrm{sGC}$, or by prodrugs which release such compounds. The main distinction used here is between substances that require the reduced heme moiety to be present in sGC and those that activate the oxidized or heme-free form of sGC. The former group includes all $\mathrm{NO}$ and $\mathrm{CO}$ releasing compounds, as well as a variety of substances which do not bind to the heme moiety but require its presence. The latter substances have been termed somewhat arbitrarily "stimulators", to distinguish them from the "activators" which activate the oxidized or heme-free enzyme_[182].

\section{Drugs targeting reduced and heme-containing sGC}

\section{NO and $\mathrm{NO}^{\circ}$ donors}

As noted previously, the NO replacement therapy using organic nitrates like GTN or isosorbide dinitrate, or the chemically unrelated sydnonimines has proven to be beneficial in the treatment of angina pectoris for more than a hundred years. Organic nitrates are prodrugs which require a biotransformation to $\mathrm{NO}$ in order to activate sGC. The enzyme responsible for the bioactivation of highly reactive nitrates like GTN in the vasculature is the mitochondrial aldehyde dehydrogenase ALDH-2_[183], whereas less potent nitrates are metabolized differently [184]. Organic nitrates have two major disadvantages: (1) nitrate tolerance, which enforces a nitrate-free interval per day in order to preserve the antianginal effect for the remainder of the time, does not permit a full protection_[185] with the notable exception of pentaerythrityl tetranitrate_[186], and (2) the metabolism of organic nitrates causes oxidative stress which further decreases the effect of the drugs_[187]. A "primary" nitrate tolerance may be a consequence of NO resistance due to smooth muscle dysfunction (see above), whereas a "secondary" tolerance is induced by continuous use and includes a decreased bioactivation of the ni- 
trates_[188]. The current status of the NO replacement therapy has been reviewed elsewhere [14,189-191]. The treatment of lung diseases with inhaled NO was also covered by a recent review_[192]. In order to provide more room for novel strategies in the present review, the reader is referred to these excellent overviews.

\section{YC-1}

Since the description of its antiplatelet activity [94], YC-1 has been tested in a variety of settings for its cardiovascular and other effects. YC-1 has well-established vasorelaxing properties on its own, and it potentiates the relaxation induced by various NO donors [97]. However, it should be kept in mind that sGC is not the only target for YC-1. For example, YC-1 is known to inhibit phosphodiesterase isoenzymes 1 through 5[193], which allows some cellular effects of YC-1 to be mediated by cAMP rather than by cGMP_[194], to relax vessels partially through an activation of large conductance $\mathrm{BK}_{\mathrm{Ca}}$ channels_[195,196], to induce NO release from endothelial cells [197], to relax human mesenteric artery partly by activating sodium pumps_[198], to protect white matter axons from nitrosative stress through sodium channel inhibition_[199], and to cause a vasoconstriction in isolated vessels of coronary artery bypass patients_[200]. Further effects of YC-1 have been summarized recently_[201]. This section focuses on those cardiovascular effects of $\mathrm{YC}-1$ which are mediated by sGC, or where an sGC-mediated mechanism has been discussed. The chemical structures of YC-1 and of other heme-dependent modulators are shown in Fig. (2).

A study comparing newborn and 2-week old piglets revealed that the sensitivity of pulmonary arteries towards $\mathrm{YC}-1$ is developmentally regulated in that $\mathrm{YC}-1$ is more potent in 2 -week old piglets. The relaxing effect of $\mathrm{YC}-1$ depended on the presence of the endothelium 
in 2-week old piglets, indicating that endogenous NO release contributes to the stronger effect of $\mathrm{YC}-1$ in these vessels. Exogenous NO also induced a stronger relaxation in the older vessels, and this effect was potentiated by YC-1 only in these vessels. [202]. These results indicate that sensitizing sGC may not be a suitable approach to treat PPHN.

O'Reilly et al. [203] tested whether YC-1 at least partially restores the vasorelaxing effects of organic nitrates even in a state of tolerance. $3 \mu \mathrm{M}$ YC-1, which by itself did not relax GTN-tolerant rabbit aortic rings, caused a 6 -fold increase of the potency of GTN, thus restoring most of the responsiveness lost due to tolerance.

Perioperative radial artery graft vasospasm is a well-known complication of coronary artery bypass grafting and may cause early graft failure. Several substances have been commonly used to relax the grafts during surgery, like phenoxybenzamine, GTN/verapamil, papaverine, and others_[204]. Ideally, the spasmolytic effect of a substance should last into the postoperative period to provide best possible protection. Of the substances mentioned above, only phenoxybenzamine (a nonspecific a-adrenoceptor antagonist which binds covalently) provides at least $24 \mathrm{~h}$ protection under clinical conditions (i.e. incubation time approx. $15 \mathrm{~min}$ ). The spasmolytic properties of YC-1 for CBG were compared to the NO donor 2-(N,N-diethylamino)diazenolate-2-oxide (DEA NONOate)_[205]. Although the EC for YC1 was higher, the same maximum relaxation was achieved with both vasodilators. In contrast to DEA NONOate, the relaxing effect of YC1 could not be completely blocked by ODQ, but with a combination of ODQ and the potassium channel blocker iberiotoxin, indicating that the relaxing effect of $\mathrm{YC}-1$ is partially due to an interaction with potassium channels. Unfortunately, the duration of the spasmolytic 
action was not investigated in this study, but due to its hydrophobic nature the action is likely to last sufficiently long to be clinically useful. To date, the metabolism of YC-1, which may also limit its duration of action, has not been investigated in vascular tissue.

Hypertension is associated with a decreased bioavailability of NO. One proposed approach to restore vascular function is to enhance the effect of the remaining NO, or to activate sGC independent of NO. In a mouse model of hypertension induced by inhibition of NOS, YC-1 was shown to retain its vasorelaxing effect completely. Both the $\mathrm{EC}_{50}$ values and the maximum effect were unaltered in hypertensive mice compared to the controls_[139]. These data confirm an earlier study performed in a similar rat model of hypertension [206]. These studies indicate that $\mathrm{YC}-1$ is a useful vasodilator to reduce blood pressure in hypertension, either used alone or in conjunction with a NO donor. However, these results must be interpreted with care as these models may not properly reflect the smooth muscle dysfunction found in SHR [141,142].

The influence of $\mathrm{YC}-1$ on the amount of neointima formed after balloon angioplasty was investigated in a rat model. YC-1 was applied as a hydrogel to the damaged site immediately after removing the catheter. The histological evaluation of vessel cross sections after 2 weeks showed a reduction of neointima formation by $\mathrm{YC}-1$ in terms of neointima area $(-74 \%)$, ratio neointima and media wall $(-72 \%)$, and neointima thickness (-76\%) [207]. The authors further showed in an VSMC cell culture model that YC-1 embedded in a hydrogel inhibited proliferation without adverse effects on viability. Moreover, platelet aggregation and adhesion to collagen were reduced by $\mathrm{YC}-1$ gel as well[208]. Thus, YC-1 applied locally after balloon angioplasty has a dual vasoprotective effect at the damaged site. An involvement 
of $\mathrm{CO}$ released by heme oxygenase is discussed but not directly shown. The authors reason that the NO synthesis is greatly reduced by the damage to the endothelium whereas HO expression is increased as a compensatory mechanism which can further be enhanced by YC-1. However, when applying YC-1 orally after balloon angioplasty in rats, the affected vessels did not show elevated cGMP contents, although a similar degree in neointima reduction was seen [209]. An analysis of the expression and the activity of the metalloproteinases MMP-2 and MMP-9, which are involved in the synthesis and restructuring of extracellular matrix, revealed that these are upregulated and more active after the angioplasty. YC-1 prevented this upregulation, and had a direct inhibitory effect on both enzymes with $\mathrm{IC}_{50}$ values in the micromolar range. Therefore it seems unlikely that the inhibition of neointima formation by $\mathrm{YC}-1$ is mediated via sGC.

\section{BAY 41-2272, BAY 41-8543, and BAY 63-2521}

BAY 41-2272 and the closely related BAY 41-8543 are the first of a series of YC-1 analogs that found widespread use as a research tool as well as testing in animal models. The history of the discovery of these and some related substances has been reviewed recently [182]. While based on the same molecular structure as YC-1, both BAY 41-2272 and BAY 41-8543 are about two orders of magnitude more potent at stimulating isolated sGC than the parent compound $[100,210]$. Although this might give BAY 41-2272 an edge over YC-1 also in terms of specificity for sGC activation, there is some evidence that the former also has cellular targets other than sGC. Similar to YC-1, BAY 41-2272 was found to inhibit PDE5_[211], but these experiments used a concentration of $200 \mu \mathrm{M}$, which is at least $1000-$ fold higher than the concentration thought to cause a biologically 
relevant elevation of cGMP through sGC activation[100,212]. Recent data suggest that vasodilation induced by BAY 41-2272 may be caused in part by a direct stimulation of the sarcolemmal sodium pump in ovine pulmonary artery [213], whereas in rat basilar artery the effect of BAY 41-2272 on the sodium pump was apparently mediated by cGMP [214] and thus remains controversial for the time being.

Both BAY 41-8543 and BAY 41-2272 exhibit long-lasting vasodilatory actions although both compounds are rapidly oxidized in vivo. However, the main metabolites of these substances act as sGC-targeted vasodilators as well, explaining the long-lasting effect_[215]. Both substances also exhibit antiplatelet effects [216,210].

BAY 41-8543 was shown to relax rabbit aortas, rabbit saphenous arteries, porcine coronary arteries, and canine femoral vein with a similar or higher potency than SNP, 3-morpholinosydnonimine (SIN1), and GTN [210]. In a rat Langendorff heart, the substance caused a drop in coronary perfusion pressure without affecting left ventricular pressure or heart rate. The substance has also a marked antiplatelet effect ex vivo. BAY 41-8543 had a blood-pressure lowering effect in normotensive rats and dogs as well as in SHR_[217]. In contrast to YC-1, BAY 41-8543 lowered the blood pressure even if applied orally.

BAY 41-2272 relaxes both endothelium-intact and denuded rabbit aorta [218]. Denuding increased the EC significantly, and the NOS inhibitor $\mathrm{N}^{\mathrm{G}}$-Nitro-L-arginine-methyl ester (L-NAME) shifted the BAY 41-2272 dose-response curve to the right in intact vessels, indicating that a part of the relaxing effect of BAY 41-2272 in intact vessels is due to a synergism with endogenously released NO. The maximum relaxing response was not affected by denuding. 
Several studies evaluated the possible beneficial effects of BAY 412272 in various models of hypertension. Transgenic mice carrying an additional copy of the renin gene react to the administration of $\mathrm{L}$ NAME with a marked increase of systolic blood pressure due to a lower basal NO synthesis. BAY 41-8543 prevented this increase of the blood pressure, and allowed all treated animals to survive after 5 weeks, whereas in the control group 9 out of 14 animals died [217]. BAY 41-2272 was equally effective in the same model. Moreover, this salutary effect persisted over 6 weeks without any signs of tolerance, and caused a marked decrease in mortality $(2$ dead animals out of 20, compared to 13 out of 19 in the control group)_[100]. In angiotensin II-induced hypertension in rats, a $10 \mathrm{mg} / \mathrm{kg}$ per day dose of BAY 41-2272 partially inhibited the rise in blood pressure_[219]. BAY 41-2272 significantly reduced the hypertension-induced increase in heart weight and positively influenced several other parameters of cardiac remodeling. The substance has a similar beneficial effect in a rat hypertension model induced by chronic administration of the NOS inhibitor L-NAME [220].

Boerrigter et al. compared the effect of BAY 41-2272 to GTN in a canine model of CHF [221]. BAY 41-2272 acted as an arterial vasodilator and reduced mean arterial pressure and pulmonary artery pressure. Both systemic and renal vascular resistance were lowered. In contrast to GTN, BAY 41-2272 did not affect right atrial pressure or pulmonary vascular resistance. Therefore, BAY 41-2272 acts solely as an arterial dilator, in contrast to GTN which is biotransformed mainly in the venous system. Furthermore BAY 41-2272 reduced pulmonary capillary wedge pressure, increased cardiac output, and increased renal blood flow. Both the cardiovascular and renoprotective effects of BAY 41-2272 seem to be useful for the treatment of CHF. 
In a lamb model of pulmonary hypertension induced by a thromboxane $\mathrm{A}_{2}$ analog, low intravenous doses of BAY 41-2272 allowed to selectively reduce mean pulmonary arterial pressure and pulmonary vascular resistance without eliciting a systemic vasodilation_[222]. BAY 41-2272 also potentiated the effect of inhaled NO, whereas inhaled $\mathrm{CO}$ did not affect the pulmonary vasoconstriction even in the presence of BAY 41-2272. The capacity of this substance to prevent or reverse pulmonary vascular remodeling was also tested in a study involving two rat models: (1) NOS-3 knockout mice and wild-type mice as a control group which both were subjected to chronic hypoxia, and (2) rats which received monocrotaline [223]. BAY 41-2272 reversed pulmonary hypertension, right heart hypertrophy, and pulmonary vascular remodeling in the wild-type mice and the monocrotaline-treated rats, but not in the knockout mice. The authors concluded that the beneficial effect of BAY 41-2272 in the treatment of pulmonary hypertension is partly dependent on endothelial NO release. In another report using hypoxia to induce pulmonary hypertension, Deruelle et al. [224] described that BAY 41-2272 prevented right ventricular hypertrophy and an hypoxia-induced increase in arterial wall thickness. The antihypertensive effect of BAY 412272 was also shown recently in a canine model of pulmonary hypertension using the interaction of heparin and protamine to induce the condition_[225]. Finally, both BAY 41-2272 and BAY 41-8543 were shown to cause pulmonary vasodilation in lambs when inhaled as microparticles_[226].

BAY 41-2272 was also found to be effective in a ovine model of PPHN_[227]. The substance reduced pulmonary vascular resistance and increased pulmonary blood flow by a sustained pulmonary vasodilation. Interestingly, the effect of BAY 41-2272 was not affected 
by the NOS inhibitor $\mathrm{N}^{\mathrm{G}}$-nitro-L-arginine, suggesting that in this model the effect of BAY 41-2272 did not depend on endothelial NO release.

BAY 63-2521, another heme-dependent sGC stimulator, was applied to patients suffering from moderate to severe pulmonary hypertension. The substance improved the main hemodynamic parameters, proved to be more effective than inhaled NO, and did not cause serious adverse events [228].

\section{CFM1571}

Another effort at compound screening resulted in the development of CFM1571 and a couple of related substances_[229]. All of these are benzydamine analogs and are thus structurally related to YC- 1 . Benzydamine itself is an antiinflammatory and analgesic compound whose mechanism of action is not well understood_[230]. The authors investigated the capacity of various modifications of the parent compound to enhance the activation of partially purified sGC in the presence of a submaximally activating dose of the NO donor DEA NONOate. The substances which showed an improved sGC activation compared to the parent compound were further tested for their antiplatelet effect, and were subjected to further tests in order to elucidate possible interactions with other enzymes of the NO/cGMP system. CFM1571 was finally selected as a stimulator of heme-containing SGC, without PDE inhibitor activity, with minor inhibition of NOS-3 and an acceptable bioavailability of $12 \%$. Unfortunately there are no comparisons with other sGC stimulators available to date, which makes it difficult to fully appreciate the potential of this compound.

\section{A-350619}

A-350619 is another heme-dependent stimulator of sGC, but this 
substance is structurally not related to YC-1[231]. A-350619 apparently uses the same binding site as $\mathrm{YC}-1$ as their effects on sGC activity are not additive. In the absence of NO, both A-350619 and YC-1 induced a 70-fold activation. In the presence of SNP, YC-1 and A-350619 activated the enzyme 160-fold and 230-fold, respectively. A-350619 showed a more pronounced effect both on $\mathrm{v}_{\text {max }}$ and $\mathrm{K}_{\mathrm{m}}$ compared to $\mathrm{YC}-1$. The substance induced a dose-dependent increase of cGMP levels in smooth muscle cells, and relaxed rabbit corpus cavernosum strips.

\section{A-778935}

( $)$-cis-3-[2-(2,2-dimethyl-propylsulfanyl)-pyridin-3-yl]-N-(3-hydroxycyclohexyl)-acrylamide (A-778935) is also based on a structure unrelated to YC-1 or any of the other known stimulators of sGC. The substance activated sGC in a synergistic fashion with the NO donor SNP, achieving an up to 420-fold activation_[232]. The activation by A-778935 could be blocked by ODQ and was strictly dependent on the presence of heme. The substance increased cGMP levels in smooth muscle cultures and relaxed rabbit corpus cavernosum strips. Both effects were further enhanced by SNP.

\section{$\mathrm{CO}$ and $\mathrm{CO}$ donor drugs}

The role of $\mathrm{CO}$ in cardiovascular function has been reviewed recently [233]. Again, the following discussion focuses on those effects of $\mathrm{CO}$ which are thought to be mediated by sGC. In contrast to the multitude of NO-releasing agents, the number of ways to deliver $\mathrm{CO}$ (besides inhaling the gas) are fairly limited. The best known members of $\mathrm{CO}$ releasing agents belong to a group of transition metal carbonyls which were reviewed recently [234,235]. The first of a series of aptly named substances (CORM $=$ CO Releasing Molecule), CORM-1 and CORM-2, were limited by their low solubility in 
aqueous media. The newer substances tricarbonylchloro(glycinato)ruthenium(II) (CORM-3) and sodium boranocarbonate (CORM-A1) are water-soluble. The latter contains the metalloid boron instead of a transition metal. These substances mainly differ in the mode and speed of CO release. CORM-3 has a half-life in aqueous solutions of approx. $1 \mathrm{~min}$, whereas the $\mathrm{CO}$ release from CORM-A1 is approx. 20 times slower.

The CORM-3 induced relaxation of rat aorta was both inhibited by the sGC inhibitor ODQ and by the potassium channel blocker glibenclamide, indicating a dual relaxing mechanism_[236]. YC-1 at a concentration of $1 \mu \mathrm{M}$, which did not have a relaxing effect on its own, further enhanced the relaxing effect of CORM-3. The administration of CORM-3 increased the cGMP levels in the vessels. Interestingly, the relaxing action of low $(100 \mu \mathrm{M})$ doses of CORM-3 depended on a functional NOS, as both the removal of the endothelium and NOS inhibition abolished the relaxing effect of this dose (higher doses still relaxed though). The authors also investigated the effect of CORM-3 infusions on the mean arterial blood pressure in rats. CORM-3 reduced the MAP significantly, but even stronger so in the presence of $\mathrm{YC}-1$. These data indicate that a $\mathrm{CO}$ releasing molecule has profound vasodilating properties in vitro and in vivo, and that a major part of this effect is brought about by sGC activation. CORM-A1 caused a slower, but stronger relaxation of rat aortic rings compared to CORM-3. This relaxation was dose-dependent and could be inhibited by myoglobin, a known CO scavenger, and by ODQ_234]. Neither NOS inhibition nor potassium channel blocking affected the relaxation by CORM-3, indicating that in contrast to CORM-3 the vasodilatory effect is entirely mediated by sGC. There was also an enhancement of the relaxation by concomitant infusion of a low dose of YC-1. CORM-A1 also induced a slow decrease of 
MAP in rats. Simultaneous administration of YC-1 both sped up and intensified the pressure drop.

Musameh et al. [237] showed an intersting differential effect of two $\mathrm{CO}$ donors on isolated perfused rat hearts, testing both constant coronary flow and constant coronary pressure. CORM-3 showed a direct positive inotropic effect with a slight reduction in heart rate in both settings, but did not affect coronary flow. CORM-A1, which releases CO slower than CORM-3, dilated the coronary vessels significantly without affecting the heart rate or contractility. The effects of CORM-3 were affected by inhibitors of sGC and of the sodium pump, but not by an inhibitor of calcium channels.

CORM-3 has also been reported to inhibit platelet aggregation. In contrast to the vascular effects described above, the antiplatelet effect appeared to be mediated by a sGC-independent mechanism. The sGC inhibitor ODQ further enhanced the antiplatelet effect, whereas YC-1 failed to do so[238].

Boissiere et al. [239] investigated the relaxing effect of CORM-2 on aortas obtained from normotensive rats and from rats made hypertensive by the Goldblatt procedure. CORM-2 relaxed the aortas of the rats independent of the level of physical exercise. However, previous exercise left the aorta of hypertensive animals even more responsive to CORM-2 than the normotensive controls, whereas exercise had no effect in the latter. Pretreatment of the vessel rings with the potassium channel blockers iberiotoxin or tetraethylammonium abolished the differences between the sedentary and exercise hypertensive groups, without abolishing the relaxing effect of CORM-2 entirely. This indicates that the $\mathrm{CO} / \mathrm{sGC}$ pathway is apparently unaffected by physical exercise, whereas the vasodilatory action mediated by potassium channels is modified. 
The irontricarbonyl complexes CORM-F3, CORM-F7, CORM-F8 and CORM-F11 are members of a new class of $\mathrm{CO}$ releasing agents [240,241]. Of these, CORM-F3 showed the highest CO release and the lowest cytotoxicity. The substance was able to relax rat aortic rings, but it was not further investigated whether the mechanism of action involved sGC.

With CO being a gas, inhalation of sublethal doses is a feasible route of administration. Several studies have investigated the cardiovascular effect of inhaled $\mathrm{CO}$, some of which have been shown to, or are likely to, be mediated by sGC activation. In a rat transplant model, Otterbein et al. [5] were able to show that atherosclerotic lesions induced by chronic graft rejection were suppressed by $\mathrm{CO}$ inhalation during the postoperative period of the experiment (56 days). In rat carotid arteries subjected to balloon dilatation, a one-hour inhalation of $\mathrm{CO}$ before the procedure suppressed neointimal hyperplasia as well. The antiproliferative effect of $\mathrm{CO}$ in smooth muscle cell cultures was blocked by the sGC inhibitor ODQ and would be mimicked by the non-hydrolyzable cGMP analog 8-Br-cGMP. A similar vasoprotective effect of $\mathrm{CO}$ in balloon-dilated vessels was also shown in Yorkshire pigs_[242]. Finally, Ramlawi et al. [243] showed in the same species that a single $1 \mathrm{~h}$-exposure to inhaled $\mathrm{CO}$ perioperatively prevents intimal hyperplasia on the venous side of an arteriovenous PTFE graft.

\section{Other drugs}

The laboratory that described the antiplatelet effects of YC-1 in 1994 [94] characterized a number of derivatives of $\mathrm{YC}-1$, which provided some insight into the structure-activity relationships of this class of molecules_[244]. Although none of these derivatives activated sGC more potently than YC-1, some turned out to be more potent PDE5 
inhibitors. Another series of YC-1 derivatives yielded several compounds with antiaggregating effects, but none of them was found to activate sGC_[245]. 3-(3[1,2,4]triazolo)-oxatriazolium-5-olate (AS-6), a member of a class of substances that have long been known for their hypotensive action in animals_[246], was shown to activate isolated porcine lung sGC 29-fold. The activation was further enhanced twofold by YC-1 and blocked by ODQ_247]. The substance was shown to decrease the perfusion pressure of an isolated rat tail artery by up to $26 \%$. The protoporphyrin IX derivates 2,4-di(1-methoxyethyl)-deuteroporphyrin IX (dimegin) and hematoporphyrin IX (HP) were found to activate SGC in human platelet cytosolic fractions 3.2-fold and 2.7-fold, respectively_[248]. The mechanism of activation of these substances is currently still unclear as it was reported to be synergistic with $\mathrm{NO}$, which would require the heme of sGC to be present instead of being replaced by one of these analogs, as the latter lack an iron for NO to interact with. Due to the limitations of the test system, the results may be explained by assuming a mixture of heme-containing and heme-deficient sGC, with NO acting on the former and the heme analogs on the latter. 
<smiles>OCc1ccc(-c2nn(Cc3ccccc3)c3ccccc23)o1</smiles>

YC-1

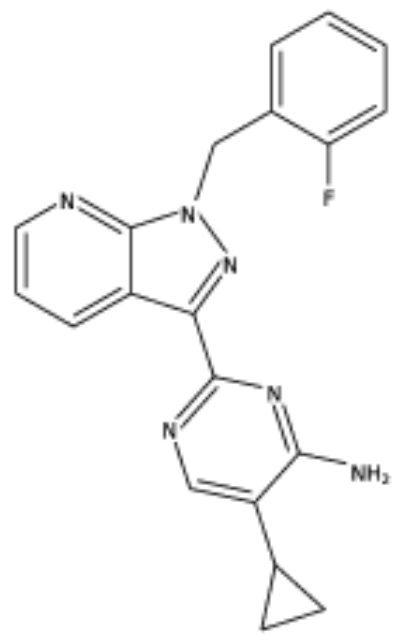

BAY 41-2272<smiles>COc1ccc(NC(=O)c2cc(OCCCN(C)C)nn2Cc2ccccc2)cc1</smiles>

CFM1571<smiles>CN(C)CCCCNC(=O)/C=C/c1ccccc1Sc1ccc(Cl)cc1</smiles>

A-350619<smiles>O=C([O-])C1(Cl)NCC(=O)C(O)(C(=O)O)N1</smiles>

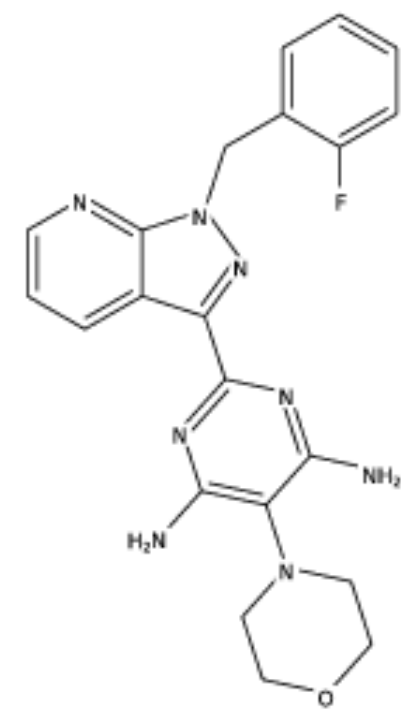

BAY $41-8543$

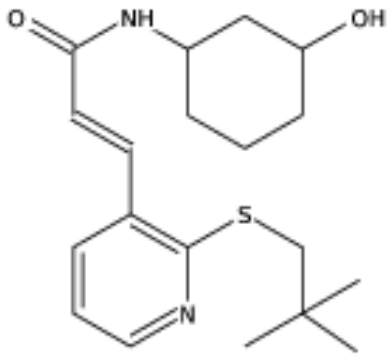

A-778935<smiles>[13CH3]C(=O)[O-]</smiles>

CORM-A1

Fig. 2: Chemical structures of heme-dependent sGC stimulators and of CO-releasing molecules (CORM-3, CORM-A1). 


\section{Drugs targeting oxidized and heme-free sGC}

As mentioned previously, oxidative stress and the resulting decreased bioavailability of endogenous $\mathrm{NO}$ are a common feature of diseases which are caused by, or are accompanied by endothelial dysfunction. Late-stage atherosclerosis has been shown to result in a type of vascular dysfunction which not only impairs the function of the endothelium, but also of the smooth muscle layer. Melichar et al. [249] found a decreased sGC expression and activity in the neointimal layer sGC along with a lower expression of some of the downstream proteins of the cGMP signalling pathway, whereas Francois et al. [250] actually found an overexpression of dysfunctional sGC in a similar hypercholesterolemic rabbit model. The resulting phenotype was dubbed "NO resistance syndrome"_[251]. The dysfunctional sGC seen in these models was later shown to be identical with heme-free sGC or sGC containing oxidized heme [252]. Obviously, the affected vessels are no longer accessible to a classical NO replacement therapy or a therapy with the above mentioned heme-dependent sGC stimulators. However, in the past couple of years a small but growing number of sGC activators were discovered which possess the unique ability to activate heme-free or oxidized sGC and thus selectively target the areas affected by the NO resistance syndrome. The chemical structures of these substances are shown in Fig. (3).

\section{BAY 58-2667}

BAY 58-2667 was another substance found in a high throughput screening effort_[111]. In contrast to stimulators like YC-1 or BAY 41-2272, the activation of purified sGC by this novel substance was actually enhanced, rather than blocked, by ODQ. Along the same lines, purified sGC rendered heme-free by detergent pretreatment was activated up to 200-fold. The group also compared the vas- 
odilatory effect of BAY 58-2667 on isolated rabbit saphenous arteries taken from nitrate-tolerant and control animals. The substance turned out to be two orders of magnitude more potent than BAY 412272, and about three orders of magnitude more potent than the NO donors SNP and SIN-1 in control animals. Furthermore, the vasodilatory response was not affected by nitrate tolerance. BAY 582667 showed antiplatelet effects both in an ex-vivo model and in the rat tail bleeding time model. In anesthesized dogs, BAY 58-2667 potently decreased mean arterial pressure, diastolic pulmonary artery pressure, and mean right atrial pressure, while showing a longer lasting action than an equipotent dose of GTN. In a later study, BAY 58-2667 was also shown to relax human mesocolon specimens of type 2 diabetic patients more effectively than those of control patients [252]. Using the transgenic renin rat model, the authors were able to show that long-term treatment with BAY 58-2667 caused a slight decrease in systolic blood pressure, in contrast to the controls which developed a noticeable hypertension. While all of the BAY 582667 treated animals survived, 9 out of 20 control animals had died at the endpoint of the study.

Three recently published studies assessed the effect of BAY 58-2667 in disease models of pulmonary hypertension and of heart failure. Using both hypoxia-induced and monocrotaline-induced models of hypertension, the intravenously administered substance proved to be as effective as BAY 41-2272 in reverting the increase in pulmonary artery blood pressure, the right ventricular hypertrophy, and the structural remodeling of the lung vasculature_[223]. This study also showed that in NOS-3 knockouts the beneficial effect of the substances was reduced, indicating that endothelial NO is required for a full protection. BAY 58-2667 inhaled as microparticles proved to be as effective as two sGC stimulators in eliciting a pulmonary vas- 
odilation in lambs_[226]. Finally, Boerrigter et al. [253] induced CHF in mongrel dogs by tachypacing at $240 \mathrm{bpm}$ for several days. Upon administering BAY 58-2667, the group found an improved cardiac output, accompanied by a significant drop in mean arterial, pulmonary artery, right atrial, and pulmonary wedge pressures. The latter two parameters indicate that BAY 58-2667 also acts as a venous dilator, in contrast to BAY 41-2272 which is solely an arterial dilator_221]. In addition the renal blood flow increased while the renal perfusion pressure decreased. The levels of the natriuretic peptides ANP and BNP decreased, suggesting an effective unloading of the heart.

Patients with acute decompensated heart failure were given BAY 582667 in $2 \mathrm{~h}$ intervals for up to $6 \mathrm{~h}$. The substance induced potent arterial and venous vasodilation, resulting in a noticeable drop of pulmonary capillary wedge pressure and reductions of both preload and afterload. Only one out of 33 patients reported an adverse event [254].

\section{HMR1766, S3448}

Two closely related anthranilic acid derivatives, HMR1766 (suggested name: ataciguat sodium) and S3448 were also shown to activate sGC with the same characteristics as BAY 58-2667_[255]. However, as the $\mathrm{EC}_{50}$ values of $\mathrm{SGC}$ activation were calculated as $0,51 \mu \mathrm{M}$ and $0,68 \mu \mathrm{M}$, respectively, these compounds are about 50 times less potent than BAY 58-2667. In cultured smooth muscle cells, HMR1766 induced a dose-dependent increase in cGMP levels which was further enhanced by ODQ. The vasodilatory effect was investigated in thoracic aortas of rats and of pigs. Both vessels were completely relaxed by $30 \mu \mathrm{M} \mathrm{S} 3448$, and there was no tachyphylaxis after an $1 \mathrm{~h}$ pretreatment. In anesthesized pigs, HMR1766 caused a long-lasting 
decrease in systolic blood pressure which was further potentiated by simultaneous administration of ODQ. The heart rate was unaffected except a slight increase during the peak hypotensive effect.

van Eickels et al. [256] investigated salutary effects of HMR1766 in a mouse model of atherosclerosis. Although the substance did not affect the blood pressure at the endpoint of the study, it significantly reduced plaque formation and improved the endothelium-dependent vasodilation. Spontaneously hypertensive rats showed improved endothelial function in the isolated aorta and a prolonged lifespan after HMR1766 treatment starting at 15 months_[257]. In a diabetic rat model chronic treatment with HMR1766 reduced ex-vivo platelet adhesion and in vivo vasodilator-stimulated phosphoprotein (VASP) phosphorylation, indicating antithrombotic effects of the substance in the treatment of endothelial dysfunction caused by diabetes [258]. 


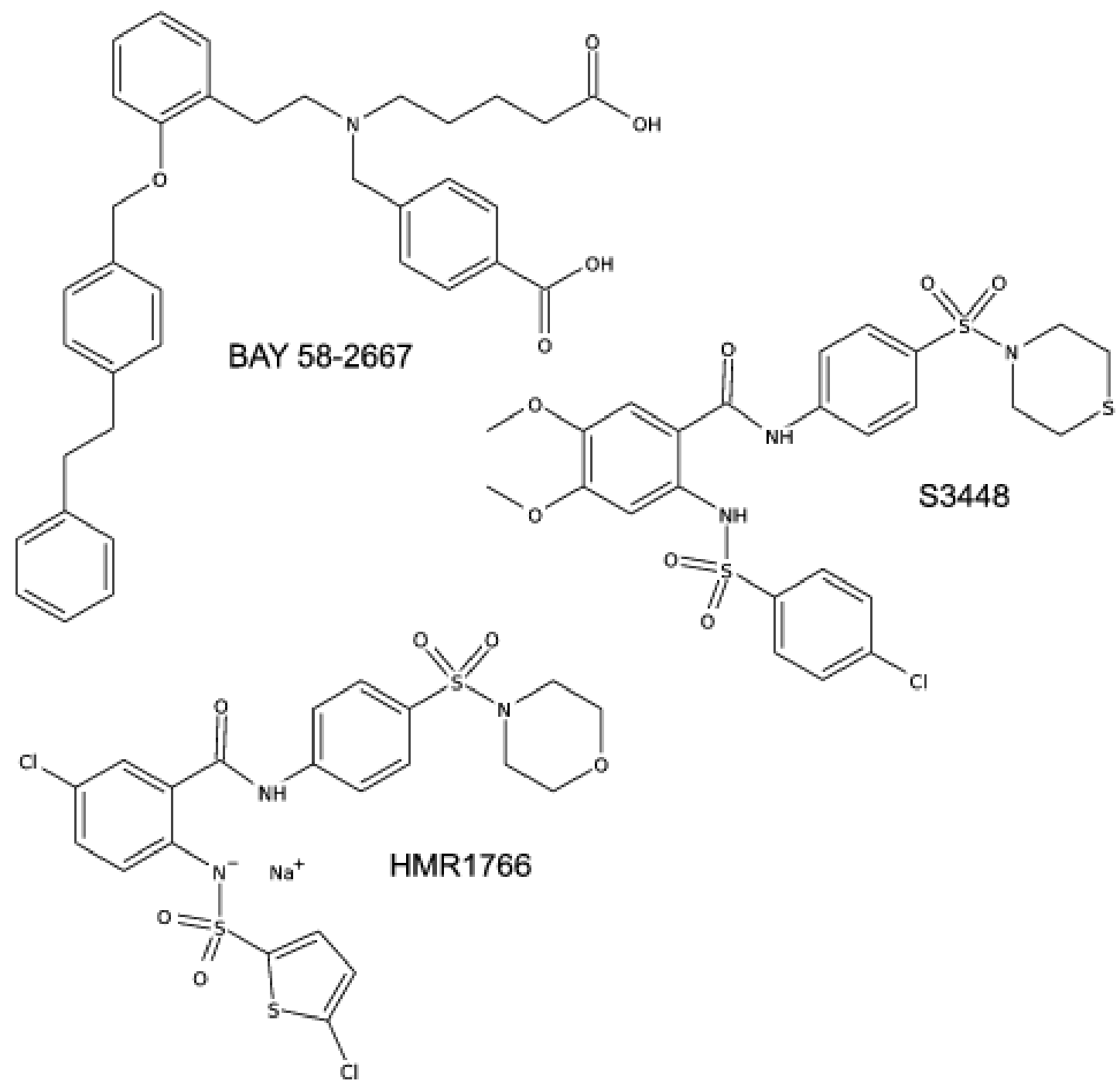

Fig. 3: Chemical structures of heme-independent sGC activators.

\section{SOLUBLE GUANYLYL CYCLASE INHIBITORS}

Just as a decreased bioavailability of NO may be overcome by an activation of sGC, an inhibition of sGC may prove useful in cases of excess NO production as an alternative to NOS inhibition [259] and to NO scavenging_[260]. The discussion of the mechanism of sGC activation presented the oxidation or removal of the heme moiety as 
one obvious way to reduce the overall cGMP synthesis. A variety of substances, some of which have been in use far longer than their mechanism of action was known, oxidize the heme of sGC with reasonable specificity to be useful as probes or in the treatment of vascular diseases. Their structures are shown in Fig. (4).

Methylene blue is best known for its use in the treatment of methemoglobinemia, as it activates the enzyme diaphorase II which is responsible for reducing methemoglobin to the oxygen carrier hemoglobin_261]. It is also an effective treatment in some forms of priapism [262] which is thought to be due at least in part to its inhibitory action on sGC_[263], a feature which it shares with the compound LY83583_[264]. Both methylene blue_[265-267] and LY83583_[265] inhibit NOS which also contributes to the cGMP-lowering effect of these substances. LY83583 has also been shown to uncouple NOS, leading to superoxide generation[268]. The oxidative action of both compounds is apparently due to the generation of hydroxyl radicals [88]. Methylene blue was further shown to activate potassium channels [269] which explains a part of its vascular effects.

In a rabbit model of anaphylactic shock induced by $\mathrm{C} 48 / 80$, Buzato et al. [270] showed that methylene blue infusion reverted the hypotension and significantly prolonged survival of the animals. In aorta segments retrieved from the animals after the study no signs of impairment of endothelium-dependent vasorelaxation were found. The same group also found methylene blue to be effective in the treatment of a small number of patients suffering from anaphylactic shock [271]. The usage of methylene blue in the treatment of septic shock has been reviewed recently [272], concluding that in spite of well-proven effects on the hemodynamics an improvement of oxygen delivery and of mortality has not been studied sufficiently.

ODQ has initially been described as a specific inhibitor of sGC [90] 
which acts by oxidizing the heme moiety [89]. However, later analyses pointed out that ODQ interacts with a variety of other heme proteins including NOS_[273]. Zingarelli et al. [274] showed in a murine model of LPS-induced sepsis that ODQ given before or as late as $4 \mathrm{~h}$ after LPS treatment significantly improved the survival rates. In isolated rat aortic rings exposed to LPS for several hours, ODQ was able to prevent (if given at the same time) or to reverse (if given $3 \mathrm{~h}$ after the LPS treatment) the loss of vascular tone.

NS 2028 also appears to inhibit sGC by oxidizing the heme moiety. The substance was shown to constrict porcine coronary arteries and to shift the dose-response-curves of the vasodilators GTN and SNP to the right_[91]. To date, the effect of NS 2028 in vasoplegic states has apparently not been studied.

A variety of other sGC inhibitors, such as $\mathrm{N}$-methylhydroxylamine [93], carnosine [275], streptonigrin_[276], artemisinin_277], and ambroxol_[278], have been described. No cardiovascular effects of the former that might involve sGC signalling have been reported to date, whereas ambroxol does act as a vasoconstrictor. However, the possible role of sGC inhibition has not been assessed_[279]. 
<smiles></smiles>

methylene blue<smiles>O=c1onc2cnc3ccccc3n12</smiles>

ODQ<smiles>O=C1C(Nc2ccccc2)=CC(=O)c2ncccc21</smiles>

LY83583<smiles>O=c1onc2n1-c1cc(Br)ccc1OC2</smiles>

NS 2028

Fig. 4: Chemical structures of heme oxidants of sGC (inhibitors).

\section{ENDOGENOUS MODULATORS OF SGC ACTIVITY}

Besides the endogenous substances $\mathrm{NO}$ and $\mathrm{CO}$, the heme content of cells appears to influence the activity of sGC. Mingone et al. [280] reported that the ratio of $\delta$-aminolaevulinic acid (a heme precursor) and iron supplementation in organ culture of endothelium-denuded bovine pulmonary artery controlled the ratio of protoporphyrin IX and heme, which in turn affected the contractile force in an organ bath. After the discovery of new heme-dependent stimulators of sGC the question arose whether there are endogenous analogs of these substances that further modulate NO or $\mathrm{CO}$ signalling. The existence of such substances was primarily postulated to lend more credibility to the $\mathrm{CO}$ hypothesis of signalling, as the sGC activation 
and vasorelaxation elicited by $\mathrm{CO}$ alone was thought too low to be of relevance compared to $\mathrm{NO}[281]$. Interestingly, in some systems like ventricular myocytes $\mathrm{CO}$ induces a stronger increase in intracellular cGMP levels than equimolar doses of the NO donor SIN-1 or of ligands of particulate guanylyl cyclases_[282]. Still there is no conclusive evidence for an "endogenous $\mathrm{YC}-1$ " to date.

This does not exclude the possibility that additional mechanisms affect the activity of sGC in vivo. Suzuki et al. [283] investigated the inhibitory effect of various organic phosphates on the activity of purified sGC. ATP, 2,3-bisphosphoglyceric acid, and inositol hexakisphosphate were found to be competitive inhibitors of the cGMP synthesis of sGC, thus affecting the basal as well as the stimulated activity of sGC. This is in contrast to the heme-oxidizing inhibitors mentioned above which do not affect the basal activity. ATP showed an additional non-competitive regulatory effect at high concentrations. Inhibition by ATP in vivo would directly link sGC activity to the metabolic state of a cell. Cardiolipin, whose involvement in the regulation of vasospasms is suspected, also inhibited sGC basal activity in this study.

Biliverdin IX is one of the products of the HO catalyzed CO synthesis. Biliverdin IX was shown to inhibit both basal and NO-stimulated sGC activity by reducing $\mathrm{v}_{\max }$ without affecting $\mathrm{K}_{\mathrm{m}}[284$ ], providing a crosstalk between $\mathrm{HO}$ and NO/cGMP signalling.

Finally, several proteins have been shown to modulate sGC activity by a direct protein-protein interaction. Geldanamycin, a HSP90 inhibitor, reduced NO-stimulated cGMP synthesis in bovine aortic endothelial cells, without affecting the basal cGMP synthesis. A direct interaction of HSP90 with the sGC protein was shown by coimmunoprecipitation and by the demonstration of their colocalization in 
bovine aortic endothelial cells and rat aorta smooth muscle cells [285]. HSP70 was also shown to interact with sGC on a protein level using the same techniques, and it increased both the basal and the NO-stimulated sGC activity_[286]. Finally, the chaperonin containing t-complex polypeptide (CCT) subunit $v$ also coprecipitated and colocalized with sGC in rat brains. The purified protein decreased the NO-stimulated sGC activity to approx. 50\%_[287]. To date, no therapies targeted at or resembling these endogenous modulators have been suggested.

\section{CONCLUSION}

Substances like GTN have been in use for decades and still provide relief from anginal pain for a vast number of patients. There is also continued progress in the development of novel NO releasing agents, although this was beyond the scope of the present review. The past couple of years saw an enormous progress in the development of therapeutical agents targeting sGC which go beyond NO replacement therapy. A variety of heme-dependent sGC stimulators allow to enhance the cGMP synthesis in the target cells to normal levels in spite of a reduced NO production or bioavailability caused by endothelial dysfunction. Animal models of hypertension, congestive heart failure, nitrate tolerance, pulmonary hypertension, and persistent pulmonary hypertension of the newborn as well as a preliminary study with patients suffering from pulmonary hypertension have demonstrated the versatility and usefulness of this therapeutical approach. In addition, a couple of CO-related strategies have emerged. Both $\mathrm{CO}$ inhalation and a variety of $\mathrm{CO}$ donors have profound vasodilatory effects, although their usefulness in animal models of sGC-related diseases remains to be shown. sGC stimulators and $\mathrm{CO}$ also appear to be useful in preventing neointima formation 
after percutaneous transluminal interventions. Even more exciting, the heme-independent sGC activators allow, for the first time, to selectively target oxidized SGC, thus allowing a site-directed effect in diseased vessels. These substances are especially promising for the treatment of late-stage atherosclerosis and other vascular diseases that result in excessive oxidative stress, as the vessels exhibit a secondary "NO resistance syndrome" which renders them mostly inaccessible to the salutary effects of NO donors and SGC stimulators. However, beneficial effects of these substances have also been shown in animal models of pulmonary hypertension and of heart failure, as well as in a preliminary study involving patients suffering from decompensated heart failure. In contrast, the evidence for long-term beneficial effects of SGC inhibition in vasoplegia and hypotension is still scarce. Although the improvement of the hemodynamics and of the oxygen delivery are undisputed, an improvement of the mortality still remains to be shown.

\section{Abbreviations}

ADMA, asymmetric dimethylarginine; ATP, adenosine triposphate; cGMP, cyclic 3',5'-guanosine monophosphate; CHF, congestive heart failure; $\mathrm{CO}$, carbon monoxide; CORM, carbon monoxide releasing molecule; CORM-3, tricarbonylchloro(glycinato)ruthenium(II); CORM-A1, sodium boranocarbonate; DEA NONOate, 2-(N,N-Diethylamino)-diazenolate-2-oxide; EDHF, endothelium-derived hyperpolarizing factor; EDRF, endothelium-derived relaxing factor; GTN, glyceryl trinitrate; GTP, guanosine triphosphate; HO, heme oxygenase; IFN, interferon; L-NAME, $\mathrm{N}^{\mathrm{G}}$-Nitro-L-arginine-methyl ester; LPS, lipopolysaccharide; LY83583, 6-anilino,5,8-quinolinedione; NO, nitric oxide; NOS, nitric oxide synthase; NS 2028, 4H-8-bromo1,2,4-oxadiazolo(3,4-d)benz(b)(1,4)oxazin-1-one; ODQ, 1H-[1,2,4]ox- 
adiazolo[4,3-a]quinoxalin-1-one; PDE, phosphodiesterase; PKG, protein kinase G; PKA, protein kinase A; PPHN, persistent pulmonary hypertension of the newborn; sGC, soluble guanylyl cyclase; SHR, spontaneously hypertensive rat; SIN-1, 3-morpholinosydnonimine; SNP, sodium nitroprusside; TNF, tumor necrosis factor; VSMC, vascular smooth muscle cells; YC-1, 3-(5'-hydroxymethyl-2'-furyl)-1benzyl indazole.

\section{References}

[1] Rapoport, R.M.; Murad, F. J. Cyclic. Nucleotide. Protein Phosphor. Res., 1983, 9, 281.

[2] Garg, U.C.; Hassid, A. J. Clin. Invest., 1989, 83, 1774.

[3] Buechler, W.A.; Ivanova, K.; Wolfram, G.; Drummer, C.; Heim, J.M.; Gerzer, R. Ann. N. Y. Acad. Sci., 1994, 714, 151.

[4] Kubes, P.; Suzuki, M.; Granger, D.N. Proc. Natl. Acad. Sci. U. S. A., $1991,88,4651$.

[5] Otterbein, L.E.; Zuckerbraun, B.S.; Haga, M.; Liu, F.; Song, R.; Usheva, A.; Stachulak, C.; Bodyak, N.; Smith, R.N.; Csizmadia, E.; Tyagi, S.; Akamatsu, Y.; Flavell, R.J.; Billiar, T.R.; Tzeng, E.; Bach, F.H.; Choi, A.M.K.; Soares, M.P. Nat. Med., 2003, 9, 183.

[6] Guo, Y.; Stein, A.B.; Wu, W.; Tan, W.; Zhu, X.; Li, Q.; Dawn, B.; Motterlini, R.; Bolli, R. Am. J. Physiol. Heart Circ. Physiol., 2004, 286, H1649.

[7] Hangaishi, M.; Ishizaka, N.; Aizawa, T.; Kurihara, Y.; Taguchi, J.; Nagai, R.; Kimura, S.; Ohno, M. Biochem. Biophys. Res. Commun., 2000, 279, 582.

[8] Duckers, H.J.; Boehm, M.; True, A.L.; Yet, S.F.; San, H.; Park, J.L.; Clinton Webb, R.; Lee, M.E.; Nabel, G.J.; Nabel, E.G. Nat. 
Med., 2001, 7, 693.

[9] Liu, M.; Jin, H.; Floten, H.S.; Ren, Z.; Yim, A.P.C.; He, G. Ann. Thorac. Surg., 2002, 73, 819.

[10] Brouard, S.; Otterbein, L.E.; Anrather, J.; Tobiasch, E.; Bach, F.H.; Choi, A.M.; Soares, M.P. J. Exp. Med., 2000, 192, 1015.

[11] Johnson, R.A.; Lavesa, M.; Askari, B.; Abraham, N.G.;

Nasjletti, A. Hypertension, 1995, 25, 166.

[12] Brüne, B.; Ullrich, V. Mol. Pharmacol., 1987, 32, 497.

[13] Lauder Brunton, T. Lancet, 1867, 90, 97.

[14] Bode-Böger, S.M.; Kojda, G. Cell. Mol. Biol. (Noisy le grand), 2005, 51, 307.

[15] Parker, J.O. Am. J. Cardiol., 1993, 72, 3C.

[16] Murrell, W. Lancet, 1879, 113, 113.

[17] Arnold, W.P.; Mittal, C.K.; Katsuki, S.; Murad, F. Proc. Natl. Acad. Sci. U. S. A., 1977, 74, 3203.

[18] Katsuki, S.; Arnold, W.P.; Murad, F. J. Cyclic. Nucleotide. Res., $1977,3,239$.

[19] Murad, F.; Mittal, C.K.; Arnold, W.P.; Katsuki, S.; Kimura, H. Adv. Cyclic. Nucleotide. Res., 1978, 9, 145.

[20] Furchgott, R.F.; Zawadzki, J.V. Nature, 1980, 288, 373.

[21] Ignarro, L.J.; Buga, G.M.; Wood, K.S.; Byrns, R.E.; Chaudhuri, G. Proc. Natl. Acad. Sci. U. S. A., 1987, 84, 9265.

[22] Murad, F. J. Clin. Invest., 1986, 78, 1.

[23] Palmer, R.M.; Ferrige, A.G.; Moncada, S. Nature, 1987, 327, 524.

[24] Schmidt, H.H.; Pollock, J.S.; Nakane, M.; Gorsky, L.D.; 
Förstermann, U.; Murad, F. Proc. Natl. Acad. Sci. U. S. A., $1991,88,365$.

[25] Ignarro, L.J. J. Mol. Cell Cardiol., 2007, .

[26] Ghafourifar, P.; Cadenas, E. Trends Pharmacol. Sci., 2005, 26, 190.

[27] Alderton, W.K.; Cooper, C.E.; Knowles, R.G. Biochem. J., 2001, 357, 593.

[28] Murad, F. N. Engl. J. Med., 2006, 355, 2003.

[29] Fleming, I.; Busse, R. Am. J. Physiol. Regul. Integr. Comp. Physiol., 2003, 284, R1.

[30] Dudzinski, D.M.; Igarashi, J.; Greif, D.; Michel, T. Annu. Rev. Pharmacol. Toxicol., 2006, 46, 235.

[31] Busse, R.; Fleming, I. Handb. Exp. Pharmacol., 2006, 43.

[32] Lirk, P.; Hoffmann, G.; Rieder, J. Curr. Drug Targets. Inflamm. Allergy., 2002, 1, 89.

[33] Naseem, K.M. Mol. Aspects. Med., 2005, 26, 33.

[34] Guzik, T.J.; Korbut, R.; Adamek-Guzik, T. J. Physiol. Pharmacol., 2003, 54, 469.

[35] Lucas, K.A.; Pitari, G.M.; Kazerounian, S.; Ruiz-Stewart, I.; Park, J.; Schulz, S.; Chepenik, K.P.; Waldman, S.A. Pharmacol. Rev., 2000, 52, 375.

[36] Wanstall, J.C.; Homer, K.L.; Doggrell, S.A. Curr. Vasc. Pharmacol., 2005, 3, 41.

[37] Conti, M.; Beavo, J. Annu. Rev. Biochem., 2007, 76, 481.

[38] Omori, K.; Kotera, J. Circ. Res., 2007, 100, 309.

[39] Sager, G. Neurochem. Int., 2004, 45, 865. 
[40] Wang, R. FASEB J., 2002, 16, 1792.

[41] Geng, B.; Yang, J.; Qi, Y.; Zhao, J.; Pang, Y.; Du, J.; Tang, C. Biochem. Biophys. Res. Commun., 2004, 313, 362.

[42] Tang, G.; Wu, L.; Liang, W.; Wang, R. Mol. Pharmacol., 2005, $68,1757$.

[43] Laggner, H.; Hermann, M.; Esterbauer, H.; Muellner, M.K.; Exner, M.; Gmeiner, B.M.; Kapiotis, S. J. Hypertens., 2007, 25, 2100.

[44] Ajioka, R.S.; Phillips, J.D.; Kushner, J.P. Biochim. Biophys. Acta, 2006, 1763, 723.

[45] Halliwell, B.; Gutteridge, J.M. Biochem. J., 1984, $219,1$.

[46] Halliwell, B.; Gutteridge, J.M. Methods Enzymol., 1984, 105, 47.

[47] Balla, J.; Vercellotti, G.M.; Jeney, V.; Yachie, A.; Varga, Z.; Jacob, H.S.; Eaton, J.W.; Balla, G. Antioxid. Redox. Signal., 2007, .

[48] Tenhunen, R.; Marver, H.S.; Schmid, R. Proc. Natl. Acad. Sci. U. S. A., 1968, 61, 748.

[49] Trakshel, G.M.; Kutty, R.K.; Maines, M.D. J. Biol. Chem., 1986, 261, 11131.

[50] McCoubrey, W.K.Jr; Huang, T.J.; Maines, M.D. Eur. J. Biochem., 1997, 247, 725.

[51] Hayashi, S.; Omata, Y.; Sakamoto, H.; Higashimoto, Y.; Hara, T.; Sagara, Y.; Noguchi, M. Gene, 2004, 336, 241.

[52] Maines, M.D. Annu. Rev. Pharmacol. Toxicol., 1997, 37, 517.

[53] Vincent, S.R.; Das, S.; Maines, M.D. Neuroscience, 1994, 63, 223. 
[54] Grundemar, L.; Johansson, M.B.; Ekelund, M.; Högestätt, E.D. Acta Physiol. Scand., 1995, 153, 203.

[55] Cook, M.N.; Nakatsu, K.; Marks, G.S.; McLaughlin, B.E.; Vreman, H.J.; Stevenson, D.K.; Brien, J.F. Can. J. Physiol. Pharmacol., 1995, 73, 515.

[56] Christodoulides, N.; Durante, W.; Kroll, M.H.; Schafer, A.I. Circulation, 1995, 91, 2306.

[57] Morita, T.; Perrella, M.A.; Lee, M.E.; Kourembanas, S. Proc. Natl. Acad. Sci. U. S. A., 1995, 92, 1475.

[58] Sammut, I.A.; Foresti, R.; Clark, J.E.; Exon, D.J.; Vesely, M.J.; Sarathchandra, P.; Green, C.J.; Motterlini, R. Br. J. Pharmacol., $1998,125,1437$.

[59] Dong, D.; Zhang, Y.; Lin, D.; Chen, J.; Patschan, S.; Goligorsky, M.S.; Nasjletti, A.; Yang, B.; Wang, W. Hypertension, 2007, 50, 643.

[60] Jaggar, J.H.; Li, A.; Parfenova, H.; Liu, J.; Umstot, E.S.; Dopico, A.M.; Leffler, C.W. Circ. Res., 2005, 97, 805.

[61] Wang, R.; Wu, L.; Wang, Z. Pflugers Arch., 1997, 434, 285.

[62] Williams, S.E.J.; Wootton, P.; Mason, H.S.; Bould, J.; Iles, D.E.; Riccardi, D.; Peers, C.; Kemp, P.J. Science, 2004, 306, 2093.

[63] Coceani, F.; Kelsey, L.; Seidlitz, E. Br. J. Pharmacol., 1996, $118,1689$.

[64] Hurley, J.H. Curr. Opin. Struct. Biol., 1998, 8, 770.

[65] Kamisaki, Y.; Saheki, S.; Nakane, M.; Palmieri, J.A.; Kuno, T.; Chang, B.Y.; Waldman, S.A.; Murad, F. J. Biol. Chem., 1986, $261,7236$. 
[66] Zabel, U.; Weeger, M.; La, M.; Schmidt, H.H. Biochem. J., 1998, 335 ( Pt 1), 51.

[67] Russwurm, M.; Behrends, S.; Harteneck, C.; Koesling, D. Biochem. J., 1998, 335 ( Pt 1), 125.

[68] Nimmegeers, S.; Sips, P.; Buys, E.; Brouckaert, P.; Van de Voorde, J. Cardiovasc. Res., 2007, 76, 149.

[69] Hoenicka, M.; Becker, E.; Apeler, H.; Sirichoke, T.; Schröder, H.; Gerzer, R.; Stasch, J. J. Mol. Med., 1999, 77, 14.

[70] Gerzer, R.; Böhme, E.; Hofmann, F.; Schultz, G. FEBS Lett., $1981,132,71$.

[71] Wedel, B.; Humbert, P.; Harteneck, C.; Foerster, J.; Malkewitz, J.; Böhme, E.; Schultz, G.; Koesling, D. Proc. Natl. Acad. Sci. U. S. A., 1994, 91, 2592.

[72] Craven, P.A.; DeRubertis, F.R. Biochim. Biophys. Acta, 1983, $745,310$.

[73] Craven, P.A.; DeRubertis, F.R. J. Biol. Chem., 1978, 253, 8433.

[74] Irvine, J.C.; Favaloro, J.L.; Kemp-Harper, B.K. Hypertension, 2003, 41, 1301.

[75] Stone, J.R.; Marletta, M.A. Biochemistry, 1994, 33, 5636.

[76] Ignarro, L.J.; Wood, K.S.; Wolin, M.S. Adv. Cyclic. Nucleotide. Protein Phosphorylation. Res., 1984, 17, 267.

[77] Ma, X.; Sayed, N.; Beuve, A.; van den Akker, F. EMBO J., 2007, 26, 578.

[78] Lawson, D.M.; Stevenson, C.E.M.; Andrew, C.R.; George, S.J.; Eady, R.R. Biochem. Soc. Trans., 2003, 31, 553.

[79] Zabel, U.; Kleinschnitz, C.; Oh, P.; Nedvetsky, P.; Smolenski, 
A.; Müller, H.; Kronich, P.; Kugler, P.; Walter, U.; Schnitzer, J.E.; Schmidt, H.H.H.W. Nat. Cell Biol., 2002, 4, 307.

[80] Linder, A.E.; McCluskey, L.P.; Cole, K.R.3rd; Lanning, K.M.; Webb, R.C. J. Pharmacol. Exp. Ther., 2005, 314, 9.

[81] Russwurm, M.; Wittau, N.; Koesling, D. J. Biol. Chem., 2001, $276,44647$.

[82] Brüne, B.; Schmidt, K.U.; Ullrich, V. Eur. J. Biochem., 1990, $192,683$.

[83] Burstyn, J.N.; Yu, A.E.; Dierks, E.A.; Hawkins, B.K.; Dawson, J.H. Biochemistry, 1995, 34, 5896.

[84] Wolin, M.S.; Wood, K.S.; Ignarro, L.J. J. Biol. Chem., 1982 , 257,13312 .

[85] Stone, J.R.; Marletta, M.A. Chem. Biol., 1998, 5, 255.

[86] Winger, J.A.; Derbyshire, E.R.; Marletta, M.A. J. Biol. Chem., 2007, 282, 897.

[87] Russwurm, M.; Koesling, D. EMBO J., 2004, 23, 4443.

[88] Kontos, H.A.; Wei, E.P. Stroke, 1993, 24, 427.

[89] Schrammel, A.; Behrends, S.; Schmidt, K.; Koesling, D.; Mayer, B. Mol. Pharmacol., 1996, 50, 1.

[90] Garthwaite, J.; Southam, E.; Boulton, C.L.; Nielsen, E.B.; Schmidt, K.; Mayer, B. Mol. Pharmacol., 1995, 48, 184.

[91] Olesen, S.P.; Drejer, J.; Axelsson, O.; Moldt, P.; Bang, L.; Nielsen-Kudsk, J.E.; Busse, R.; Mülsch, A. Br. J. Pharmacol., 1998, 123, 299.

[92] Zhao, Y.; Brandish, P.E.; DiValentin, M.; Schelvis, J.P.; Babcock, G.T.; Marletta, M.A. Biochemistry, 2000, 39, 10848. 
[93] Deguchi, T.; Saito, M.; Kono, M. Biochim. Biophys. Acta, 1978, $544,8$.

[94] Ko, F.N.; Wu, C.C.; Kuo, S.C.; Lee, F.Y.; Teng, C.M. Blood, $1994,84,4226$.

[95] Wu, C.C.; Ko, F.N.; Kuo, S.C.; Lee, F.Y.; Teng, C.M. Br. J. Pharmacol., 1995, 116, 1973.

[96] Martin, E.; Lee, Y.C.; Murad, F. Proc. Natl. Acad. Sci. U. S. A., $2001,98,12938$.

[97] Mülsch, A.; Bauersachs, J.; Schäfer, A.; Stasch, J.P.; Kast, R.;

Busse, R. Br. J. Pharmacol., 1997, 120, 681.

[98] Friebe, A.; Koesling, D. Mol. Pharmacol., 1998, 53, 123.

[99] Friebe, A.; Schultz, G.; Koesling, D. EMBO J., 1996, 15, 6863.

[100] Stasch, J.P.; Becker, E.M.; Alonso-Alija, C.; Apeler, H.;

Dembowsky, K.; Feurer, A.; Gerzer, R.; Minuth, T.; Perzborn,

E.; Pleiss, U.; Schröder, H.; Schroeder, W.; Stahl, E.; Steinke,

W.; Straub, A.; Schramm, M. Nature, 2001, 410, 212.

[101] Denninger, J.W.; Schelvis, J.P.; Brandish, P.E.; Zhao, Y.;

Babcock, G.T.; Marletta, M.A. Biochemistry, 2000, 39, 4191.

[102] Russwurm, M.; Mergia, E.; Mullershausen, F.; Koesling, D. J. Biol. Chem., 2002, 277, 24883.

[103] Sopková-De Oliveira Santos, J.; Collot, V.; Bureau, I.; Rault,

S. Acta Crystallogr. C., 2000, 56 ( Pt 8), 1035.

[104] Becker, E.; Wunder, F.; Kast, R.; Robyr, C.; Hoenicka, M.;

Gerzer, R.; Schröder, H.; Stasch, J. Nitric Oxide, 1999, 3, 55.

[105] Buechler, W.A.; Singh, S.; Aktas, J.; Müller, S.; Murad, F.;

Gerzer, R. Adv. Pharmacol., 1995, 34, 293.

[106] Makino, R.; Obayashi, E.; Homma, N.; Shiro, Y.; Hori, H. J. 
Biol. Chem., 2003, 278, 11130.

[107] Schmidt, P.; Schramm, M.; Schröder, H.; Stasch, J. Eur. J.

Pharmacol., 2003, 468, 167.

[108] Friebe, A.; Schultz, G.; Koesling, D. EMBO J., 1996, 15, 6863.

[109] Koesling, D.; Russwurm, M.; Mergia, E.; Mullershausen, F.;

Friebe, A. Neurochem. Int., 2004, 45, 813.

[110] Ignarro, L.J.; Wood, K.S.; Wolin, M.S. Proc. Natl. Acad. Sci. U. S. A., 1982, 79, 2870.

[111] Stasch, J.; Schmidt, P.; Alonso-Alija, C.; Apeler, H.;

Dembowsky, K.; Haerter, M.; Heil, M.; Minuth, T.; Perzborn, E.;

Pleiss, U.; Schramm, M.; Schroeder, W.; Schröder, H.; Stahl,

E.; Steinke, W.; Wunder, F. Br. J. Pharmacol., 2002, 136, 773.

[112] Schmidt, P.M.; Schramm, M.; Schröder, H.; Wunder, F.;

Stasch, J. J. Biol. Chem., 2004, 279, 3025.

[113] Hansson, G.K. N. Engl. J. Med., 2005, 352, 1685.

[114] Jayakody, L.; Kappagoda, T.; Senaratne, M.P.; Thomson, A.B. Br. J. Pharmacol., 1988, 94, 335.

[115] Félétou, M.; Vanhoutte, P.M. Am. J. Physiol. Heart Circ.

Physiol., 2006, 291, H985.

[116] Ross, R.; Glomset, J.A. Science, 1973, 180, 1332.

[117] Feil, R.; Feil, S.; Hofmann, F. Trends Mol. Med., 2005, 11, 71.

[118] Yang, Z.; Ming, X. Clin. Med. Res., 2006, 4, 53.

[119] Gewaltig, M.T.; Kojda, G. Cardiovasc. Res., 2002, 55, 250.

[120] Siow, R.C.; Sato, H.; Mann, G.E. Cardiovasc. Res., 1999, 41, 385. 
[121] Hoekstra, K.A.; Godin, D.V.; Cheng, K.M. Biochem. Cell Biol., 2004, 82, 351.

[122] Tashiro, T.; Morishige, N.; Iwahashi, H.; Hayashida, Y.;

Takeuchi, K.; Ito, N. Ann. Thorac. Cardiovasc. Surg., 2007, 13, 5 .

[123] Weintraub, W.S. Am. J. Cardiol., 2007, 100, 3K.

[124] Shimokawa, H.; Flavahan, N.A.; Vanhoutte, P.M. Circ. Res., $1989,65,740$.

[125] Ahanchi, S.S.; Tsihlis, N.D.; Kibbe, M.R. J. Vasc. Surg., 2007, 45 Suppl A, A64.

[126] Hannan, E.L.; Racz, M.J.; Walford, G.; Jones, R.H.; Ryan, T.J.; Bennett, E.; Culliford, A.T.; Isom, O.W.; Gold, J.P.; Rose, E.A. N. Engl. J. Med., 2005, 352, 2174.

[127] Abbott, W.M.; Megerman, J.; Hasson, J.E.; L'Italien, G.;

Warnock, D.F. J. Vasc. Surg., 1987, 5, 376.

[128] Sarkar, S.; Salacinski, H.J.; Hamilton, G.; Seifalian, A.M. Eur. J. Vasc. Endovasc. Surg., 2006, 31, 627.

[129] Motwani, J.G.; Topol, E.J. Circulation, 1998, 97, 916.

[130] Komori, K. Nagoya. J. Med. Sci., 2003, 66, 9.

[131] Lau, G.T.; Lowe, H.C.; Kritharides, L. Semin. Vasc. Med., 2004, 4, 153.

[132] Tulis, D.A.; Keswani, A.N.; Peyton, K.J.; Wang, H.; Schafer, A.I.; Durante, W. Cell Mol. Biol. (Noisy le grand), 2005, 51, 441.

[133] Miyata, N.; Tsuchida, K.; Tanaka, M.; Otomo, S. J. Pharm. Pharmacol., 1990, 42, 763.

[134] King, A.J.; Mercer, P.; Troy, J.L.; Brenner, B.M. J. Am. Soc. Nephrol., 1991, 2, 1072. 
[135] Tomita, T.; Onda, T.; Mashiko, S.; Hamano, M.; Tomita, I. Clin. Exp. Pharmacol. Physiol. Suppl., 1995, 22, S139.

[136] Price, D.T.; Vita, J.A.; Keaney, J.F.Jr Antioxid. Redox. Signal., 2000, 2, 919 .

[137] Lüscher, T.F.; Diederich, D.; Weber, E.; Vanhoutte, P.M.;

Bühler, F.R. Hypertension, 1988, 11, 573.

[138] Münzel, T.; Daiber, A.; Ullrich, V.; Mülsch, A. Arterioscler.

Thromb. Vasc. Biol., 2005, 25, 1551.

[139] Linder, A.E.; Weber, D.S.; Whitesall, S.E.; D'Alecy, L.G.;

Webb, R.C. J. Cardiovasc. Pharmacol., 2005, 46, 438.

[140] López-Farré, A.; Rodriguez-Feo, J.A.; García-Colis, E.; Gomez, J.; López-Blaya, A.; Fortes, J.; de Andrés, R.; Rico, L.; Casado, S. J. Hypertens., 2002, 20, 463.

[141] Klöss, S.; Bouloumié, A.; Mülsch, A. Hypertension, 2000, 35, 43.

[142] Ruetten, H.; Zabel, U.; Linz, W.; Schmidt, H.H. Circ. Res., $1999,85,534$.

[143] Ndisang, J.F.; Zhao, W.; Wang, R. Hypertension, 2002, 40, 315.

[144] Ndisang, J.F.; Tabien, H.E.N.; Wang, R. J. Hypertens., 2004, 22, 1057.

[145] Imai, T.; Morita, T.; Shindo, T.; Nagai, R.; Yazaki, Y.;

Kurihara, H.; Suematsu, M.; Katayama, S. Circ. Res., 2001, 89, 55 .

[146] Klinger, J.R. Clin. Chest Med., 2007, 28, 143.

[147] Cogolludo, A.; Moreno, L.; Villamor, E. Pharmacology, 2007, $79,65$. 
[148] Hoeper, M.M.; Rubin, L.J. Am. J. Respir. Crit. Care Med., 2006, 173, 499.

[149] Humbert, M.; Morrell, N.W.; Archer, S.L.; Stenmark, K.R.;

MacLean, M.R.; Lang, I.M.; Christman, B.W.; Weir, E.K.;

Eickelberg, O.; Voelkel, N.F.; Rabinovitch, M. J. Am. Coll.

Cardiol., 2004, 43, 13S.

[150] Pullamsetti, S.; Kiss, L.; Ghofrani, H.A.; Voswinckel, R.;

Haredza, P.; Klepetko, W.; Aigner, C.; Fink, L.; Muyal, J.P.;

Weissmann, N.; Grimminger, F.; Seeger, W.; Schermuly, R.T.

FASEB J., 2005, 19, 1175.

[151] Wells, S.M.; Holian, A. Am. J. Respir. Cell Mol. Biol., 2007, 36, 520.

[152] Xu, W.; Kaneko, F.T.; Zheng, S.; Comhair, S.A.A.; Janocha, A.J.; Goggans, T.; Thunnissen, F.B.J.M.; Farver, C.; Hazen, S.L.; Jennings, C.; Dweik, R.A.; Arroliga, A.C.; Erzurum, S.C. FASEB J., 2004, 18, 1746.

[153] Khoo, J.P.; Zhao, L.; Alp, N.J.; Bendall, J.K.; Nicoli, T.;

Rockett, K.; Wilkins, M.R.; Channon, K.M. Circulation, 2005, $111,2126$.

[154] Pepke-Zaba, J.; Higenbottam, T.W.; Dinh-Xuan, A.T.; Stone, D.; Wallwork, J. Lancet, 1991, 338, 1173.

[155] Brilli, R.J.; Krafte-Jacobs, B.; Smith, D.J.; Passerini, D.;

Moore, L.; Ballard, E.T. Crit. Care Med., 1998, 26, 1390.

[156] Abman, S.H. Neonatology., 2007, 91, 283.

[157] Grover, T.R.; Zenge, J.P.; Parker, T.A.; Abman, S.H. Pediatr. Res., 2002, 52, 907.

[158] Grover, T.R.; Parker, T.A.; Zenge, J.P.; Markham, N.E.; 
Kinsella, J.P.; Abman, S.H. Am. J. Physiol. Lung Cell Mol. Physiol., 2003, 284, L508.

[159] Lassus, P.; Turanlahti, M.; Heikkilä, P.; Andersson, L.C.;

Nupponen, I.; Sarnesto, A.; Andersson, S. Am. J. Respir. Crit. Care Med., 2001, 164, 1981.

[160] Konduri, G.G.; Bakhutashvili, I.; Eis, A.; Pritchard, K.Jr Am. J. Physiol. Heart Circ. Physiol., 2007, 292, H1812.

[161] Mata-Greenwood, E.; Jenkins, C.; Farrow, K.N.; Konduri, G.G.; Russell, J.A.; Lakshminrusimha, S.; Black, S.M.; Steinhorn, R.H. Am. J. Physiol. Lung Cell Mol. Physiol., 2006, 290, L232.

[162] Ennezat, P.V.; Van Belle, E.; Asseman, P.; Cohen-Solal, A.; Evans, T.; Lejemtel, T.H. Acta Cardiol., 2007, 62, 265.

[163] Chen, Y.; Li, Y.; Zhang, P.; Traverse, J.H.; Hou, M.; Xu, X.; Kimoto, M.; Bache, R.J. Am. J. Physiol. Heart Circ. Physiol., 2005, 289, H2212.

[164] Dixon, L.J.; Morgan, D.R.; Hughes, S.M.; McGrath, L.T.; ElSherbeeny, N.A.; Plumb, R.D.; Devine, A.; Leahey, W.; Johnston, G.D.; McVeigh, G.E. Circulation, 2003, 107, 1725.

[165] Elkayam, U.; Mehra, A.; Shotan, A.; Ostrzega, E. Am. J. Cardiol., 1992, 70, 98B.

[166] Ferreiro, C.R.; Chagas, A.C.P.; Carvalho, M.H.C.; Dantas, A.P.; Scavone, C.; Souza, L.C.B.; Buffolo, E.; da Luz, P.L. Braz. J. Med. Biol. Res., 2004, 37, 1313.

[167] Damy, T.; Ratajczak, P.; Shah, A.M.; Camors, E.; Marty, I.; Hasenfuss, G.; Marotte, F.; Samuel, J.; Heymes, C. Lancet, 2004, 363, 1365. 
[168] Booz, G.W. Hypertension, 2005, 45, 341.

[169] Freedman, J.E.; Loscalzo, J. J. Thromb. Haemost., 2003, 1, 1183.

[170] Loscalzo, J. Circ. Res., 2001, 88, 756.

[171] Blann, A.D. Pathophysiol. Haemost. Thromb., 2004, 33, 445.

[172] Falk, E. Circulation, 1985, 71, 699.

[173] DeWood, M.A.; Spores, J.; Notske, R.; Mouser, L.T.;

Burroughs, R.; Golden, M.S.; Lang, H.T. N. Engl. J. Med., 1980, 303, 897.

[174] Cauwels, A. Kidney Int., 2007, 72, 557.

[175] Goode, H.F.; Howdle, P.D.; Walker, B.E.; Webster, N.R. Clin. Sci. (Lond), 1995, 88, 131.

[176] Tsukahara, Y.; Morisaki, T.; Horita, Y.; Torisu, M.; Tanaka, M. World J. Surg., 1998, 22, 771.

[177] Bultinck, J.; Sips, P.; Vakaet, L.; Brouckaert, P.; Cauwels, A. FASEB J., 2006, 20, 2363.

[178] Khadour, F.H.; Panas, D.; Ferdinandy, P.; Schulze, C.; Csont, T.; Lalu, M.M.; Wildhirt, S.M.; Schulz, R. Am. J. Physiol. Heart Circ. Physiol., 2002, 283, H1108.

[179] Petros, A.; Lamb, G.; Leone, A.; Moncada, S.; Bennett, D.;

Vallance, P. Cardiovasc. Res., 1994, 28, 34.

[180] Cobb, J.P.; Natanson, C.; Hoffman, W.D.; Lodato, R.F.;

Banks, S.; Koev, C.A.; Solomon, M.A.; Elin, R.J.; Hosseini,

J.M.; Danner, R.L. J. Exp. Med., 1992, 176, 1175.

[181] Johnson, R.A.; Johnson, F.K. Shock, 2007, .

[182] Evgenov, O.V.; Pacher, P.; Schmidt, P.M.; Haskó, G.; Schmidt, 
H.H.H.W.; Stasch, J. Nat. Rev. Drug Discov., 2006, 5, 755.

[183] Chen, Z.; Zhang, J.; Stamler, J.S. Proc. Natl. Acad. Sci. U. S. A., 2002, 99, 8306.

[184] Wenzel, P.; Hink, U.; Oelze, M.; Seeling, A.; Isse, T.; Bruns, K.; Steinhoff, L.; Brandt, M.; Kleschyov, A.L.; Schulz, E.; Lange, K.; Weiner, H.; Lehmann, J.; Lackner, K.J.; Kawamoto, T.;

Münzel, T.; Daiber, A. Br. J. Pharmacol., 2007, 150, 526.

[185] Gori, T.; Parker, J.D. Circulation, 2002, 106, 2510.

[186] Koenig, A.; Lange, K.; Konter, J.; Daiber, A.; Stalleicken, D.; Glusa, E.; Lehmann, J. J. Cardiovasc. Pharmacol., 2007, 50, 68.

[187] Münzel, T.; Sayegh, H.; Freeman, B.A.; Tarpey, M.M.; Harrison, D.G. J. Clin. Invest., 1995, 95, 187.

[188] Fayers, K.E.; Cummings, M.H.; Shaw, K.M.; Laight, D.W. Br. J. Clin. Pharmacol., 2003, 56, 620.

[189] Mason, R.P.; Cockcroft, J.R. J. Clin. Hypertens. (Greenwich)., 2006, 8, 40 .

[190] Thatcher, G.R.J.; Nicolescu, A.C.; Bennett, B.M.; Toader, V. Free Radic. Biol. Med., 2004, 37, 1122.

[191] Katsumi, H.; Nishikawa, M.; Hashida, M. Cardiovasc.

Hematol. Agents Med. Chem., 2007, 5, 204.

[192] Bloch, K.D.; Ichinose, F.; Roberts, J.D.Jr; Zapol, W.M.

Cardiovasc. Res., 2007, 75, 339.

[193] Galle, J.; Zabel, U.; Hübner, U.; Hatzelmann, A.; Wagner, B.;

Wanner, C.; Schmidt, H.H. Br. J. Pharmacol., 1999, 127, 195.

[194] Hwang, T.; Hung, H.; Kao, S.; Teng, C.; Wu, C.; Cheng, S.J. Mol. Pharmacol., 2003, 64, 1419. 
[195] Teixeira, C.E.; Priviero, F.B.M.; Webb, R.C. J. Pharmacol. Exp. Ther., 2006, 317, 258.

[196] Seitz, S.; Wegener, J.W.; Rupp, J.; Watanabe, M.; Jost, A.;

Gerhard, R.; Shainberg, A.; Ochi, R.; Nawrath, H. Eur. J.

Pharmacol., 1999, 382, 11.

[197] Wohlfart, P.; Malinski, T.; Ruetten, H.; Schindler, U.; Linz, W.;

Schoenafinger, K.; Strobel, H.; Wiemer, G. Br. J. Pharmacol,, 1999, 128, 1316.

[198] Slupski, M.; Szadujkis-Szadurski, L.; Grzesk, G.; Szadujkis-

Szadurski, R.; Szadujkis-Szadurska, K.; Wlodarczyk, Z.;

Masztalerz, M.; Piotrowiak, I.; Jasinski, M. Transplant. Proc., 2007, 39, 1350 .

[199] Garthwaite, G.; Goodwin, D.A.; Neale, S.; Riddall, D.;

Garthwaite, J. Mol. Pharmacol., 2002, 61, 97.

[200] Hoenicka, M.; Keyser, A.; Floerchinger, B.; Hirt, S.;

Birnbaum, D.E.; Schmid, C. J. Pharmacol. Exp. Ther. 2008 (submitted).

[201] Tulis, D.A. Curr. Med. Chem. Cardiovasc. Hematol. Agents, 2004, 2, 343.

[202] González-Luis, G.; Cogolludo, A.; Moreno, L.; Lodi, F.;

Tamargo, J.; Pérez-Vizcaíno, F.; Villamor, E. Biol. Neonate., 2006, 90, 66 .

[203] O'Reilly, D.A.; McLaughlin, B.E.; Marks, G.S.; Brien, J.F.;

Nakatsu, K. Can. J. Physiol. Pharmacol., 2001, 79, 43.

[204] Mussa, S.; Guzik, T.J.; Black, E.; Dipp, M.A.; Channon, K.M.;

Taggart, D.P. J. Thorac. Cardiovasc. Surg., 2003, 126, 1798.

[205] Berkan, O.; Bagcivan, I.; Kaya, T.; Yildirim, K.; Yildirim, S.; 
Dogan, K. Can. J. Physiol. Pharmacol., 2007, 85, 521.

[206] Rothermund, L.; Friebe, A.; Paul, M.; Koesling, D.; Kreutz, R.

Br. J. Pharmacol., 2000, 130, 205.

[207] Tulis, D.A.; Durante, W.; Peyton, K.J.; Chapman, G.B.;

Evans, A.J.; Schafer, A.I. Biochem. Biophys. Res. Commun., 2000, 279, 646.

[208] Tulis, D.A.; Bohl Masters, K.S.; Lipke, E.A.; Schiesser, R.L.;

Evans, A.J.; Peyton, K.J.; Durante, W.; West, J.L.; Schafer, A.I.

Biochem. Biophys. Res. Commun., 2002, 291, 1014.

[209] Liu, Y.; Pan, S.; Peng, C.; Guh, J.; Huang, D.; Chang, Y.; Lin, C.; Pai, H.; Kuo, S.; Lee, F.; Teng, C. J. Pharmacol. Exp. Ther., 2006, 316, 35.

[210] Stasch, J.; Alonso-Alija, C.; Apeler, H.; Dembowsky, K.;

Feurer, A.; Minuth, T.; Perzborn, E.; Schramm, M.; Straub, A.

Br. J. Pharmacol., 2002, 135, 333.

[211] Mullershausen, F.; Russwurm, M.; Friebe, A.; Koesling, D. Circulation, 2004, 109, 1711.

[212] Bischoff, E.; Stasch, J. Circulation, 2004, 110, e320.

[213] Bawankule, D.U.; Sathishkumar, K.; Sardar, K.K.; Chanda, D.; Krishna, A.V.; Prakash, V.R.; Mishra, S.K. J. Pharmacol. Exp. Ther., 2005, 314, 207.

[214] Teixeira, C.E.; Priviero, F.B.M.; Todd, J.Jr; Webb, R.C. Hypertension, 2006, 47, 596.

[215] Straub, A.; Benet-Buchholz, J.; Fröde, R.; Kern, A.;

Kohlsdorfer, C.; Schmitt, P.; Schwarz, T.; Siefert, H.M.; Stasch, J.P. Bioorg. Med. Chem., 2002, 10, 1711.

[216] Hobbs, A.J.; Moncada, S. Vascul. Pharmacol., 2003, 40, 149. 
[217] Stasch, J.; Dembowsky, K.; Perzborn, E.; Stahl, E.; Schramm, M. Br. J. Pharmacol., 2002, 135, 344.

[218] Priviero, F.B.M.; Baracat, J.S.; Teixeira, C.E.; Claudino, M.A.; de Nucci, G.; Antunes, E. Clin. Exp. Pharmacol. Physiol., 2005, 32,728 .

[219] Masuyama, H.; Tsuruda, T.; Kato, J.; Imamura, T.; Asada, Y.; Stasch, J.; Kitamura, K.; Eto, T. Hypertension, 2006, 48, 972.

[220] Zanfolin, M.; Faro, R.; Araujo, E.G.; Guaraldo, A.M.A.; Antunes, E.; de Nucci, G. J. Cardiovasc. Pharmacol., 2006, 47, 391.

[221] Boerrigter, G.; Costello-Boerrigter, L.C.; Cataliotti, A.; Tsuruda, T.; Harty, G.J.; Lapp, H.; Stasch, J.; Burnett, J.C.Jr Circulation, 2003, 107, 686.

[222] Evgenov, O.V.; Ichinose, F.; Evgenov, N.V.; Gnoth, M.J.; Falkowski, G.E.; Chang, Y.; Bloch, K.D.; Zapol, W.M. Circulation, 2004, 110, 2253.

[223] Dumitrascu, R.; Weissmann, N.; Ghofrani, H.A.; Dony, E.; Beuerlein, K.; Schmidt, H.; Stasch, J.; Gnoth, M.J.; Seeger, W.; Grimminger, F.; Schermuly, R.T. Circulation, 2006, 113, 286.

[224] Deruelle, P.; Balasubramaniam, V.; Kunig, A.M.; Seedorf, G.J.; Markham, N.E.; Abman, S.H. Biol. Neonate., 2006, 90, 135.

[225] Freitas, C.F.; Morganti, R.P.; Annichino-Bizzacchi, J.M.; de Nucci, G.; Antunes, E. Clin. Exp. Pharmacol. Physiol., 2007, 34, 10.

[226] Evgenov, O.V.; Kohane, D.S.; Bloch, K.D.; Stasch, J.; Volpato, G.P.; Bellas, E.; Evgenov, N.V.; Buys, E.S.; Gnoth, M.J.; Graveline, A.R.; Liu, R.; Hess, D.R.; Langer, R.; Zapol, W.M. 
Am. J. Respir. Crit. Care Med., 2007, .

[227] Deruelle, P.; Grover, T.R.; Storme, L.; Abman, S.H. Am. J.

Physiol. Lung Cell Mol. Physiol., 2005, 288, L727.

[228] Ghofrani, H.A.; Weimann, G.; Frey, R.; Voswinckel, R.;

Thamm, M.; Bölkow, D.; Weissmann, N.; Mück, W.; Unger, S.;

Wensing, G.; Schermuly, R.T.; Grimminger, F. BMC

Pharmacology, 2007, 7, s8.

[229] Selwood, D.L.; Brummell, D.G.; Budworth, J.; Burtin, G.E.;

Campbell, R.O.; Chana, S.S.; Charles, I.G.; Fernandez, P.A.;

Glen, R.C.; Goggin, M.C.; Hobbs, A.J.; Kling, M.R.; Liu, Q.;

Madge, D.J.; Meillerais, S.; Powell, K.L.; Reynolds, K.; Spacey,

G.D.; Stables, J.N.; Tatlock, M.A.; Wheeler, K.A.; Wishart, G.;

Woo, C.K. J. Med. Chem., 2001, 44, 78.

[230] Müller-Peddinghaus, R. Arzneimittelforschung., 1987, 37, 635.

[231] Miller, L.N.; Nakane, M.; Hsieh, G.C.; Chang, R.; Kolasa, T.;

Moreland, R.B.; Brioni, J.D. Life Sci., 2003, 72, 1015.

[232] Nakane, M.; Kolasa, T.; Chang, R.; Miller, L.N.; Moreland,

R.B.; Brioni, J.D. J. Pharmacol. Sci., 2006, 102, 231.

[233] Durante, W.; Johnson, F.K.; Johnson, R.A. J. Cell Mol. Med., 2006, 10, 672 .

[234] Motterlini, R.; Mann, B.E.; Foresti, R. Expert. Opin. Investig. Drugs, 2005, 14, 1305.

[235] Alberto, R.; Motterlini, R. Dalton. Trans., 2007, 1651.

[236] Foresti, R.; Hammad, J.; Clark, J.E.; Johnson, T.R.; Mann, B.E.; Friebe, A.; Green, C.J.; Motterlini, R. Br. J. Pharmacol., $2004,142,453$. 
[237] Musameh, M.D.; Fuller, B.J.; Mann, B.E.; Green, C.J.;

Motterlini, R. Br. J. Pharmacol., 2006, 149, 1104.

[238] Chlopicki, S.; Olszanecki, R.; Marcinkiewicz, E.; Lomnicka, M.; Motterlini, R. Cardiovasc. Res., 2006, 71, 393.

[239] Boissiere, J.; Lemaire, M.; Antier, D.; Courteix, D.; Bonnet, P. Med. Sci. Sports Exerc., 2006, 38, 652.

[240] Sawle, P.; Hammad, J.; Fairlamb, I.J.S.; Moulton, B.; O'Brien, C.T.; Lynam, J.M.; Duhme-Klair, A.K.; Foresti, R.; Motterlini, R. J. Pharmacol. Exp. Ther., 2006, 318, 403.

[241] Fairlamb, I.J.S.; Duhme-Klair, A.; Lynam, J.M.; Moulton, B.E.; O'Brien, C.T.; Sawle, P.; Hammad, J.; Motterlini, R. Bioorg. Med. Chem. Lett., 2006, 16, 995.

[242] Raman, K.G.; Barbato, J.E.; Ifedigbo, E.; Ozanich, B.A.; Zenati, M.S.; Otterbein, L.E.; Tzeng, E. J. Vasc. Surg., 2006, 44, 151.

[243] Ramlawi, B.; Scott, J.R.; Feng, J.; Mieno, S.; Raman, K.G.; Gallo, D.; Csizmadia, E.; Yoke Chin, B.; Bach, F.H.; Otterbein, L.E.; Sellke, F.W. J. Surg. Res., 2007, 138, 121.

[244] Lee, F.Y.; Lien, J.C.; Huang, L.J.; Huang, T.M.; Tsai, S.C.; Teng, C.M.; Wu, C.C.; Cheng, F.C.; Kuo, S.C. J. Med. Chem., $2001,44,3746$.

[245] Cwiklicki, A.; Rehse, K. Arch. Pharm. (Weinheim)., 2004, 337, 156.

[246] Kier, L.B.; al-Shamma, A.; Campbell, D.; Patil, P.N.; Tye, A. Nature, 1966, 210, 742.

[247] Bonartsev, A.; Postnikov, A.; Artemieva, M.; Medvedeva, N. BMC Pharmacology, 2005, 5, P6. 
[248] Severina, I.S.; Pyatakova, N.V.; Shchegolev, A.Y.; Ponomarev, G.V. Biochemistry (Mosc)., 2006, 71, 340.

[249] Melichar, V.O.; Behr-Roussel, D.; Zabel, U.; Uttenthal, L.O.; Rodrigo, J.; Rupin, A.; Verbeuren, T.J.; Kumar H S, A.; Schmidt, H.H.H.W. Proc. Natl. Acad. Sci. U. S. A., 2004, 101, 16671.

[250] Francois, M.; Kojda, G. Neurochem. Int., 2004, 45, 955.

[251] Gladwin, M.T. J. Clin. Invest., 2006, 116, 2330.

[252] Stasch, J.; Schmidt, P.M.; Nedvetsky, P.I.; Nedvetskaya, T.Y.; H S, A.K.; Meurer, S.; Deile, M.; Taye, A.; Knorr, A.; Lapp, H.; Müller, H.; Turgay, Y.; Rothkegel, C.; Tersteegen, A.; KempHarper, B.; Müller-Esterl, W.; Schmidt, H.H.H.W. J. Clin. Invest., 2006, 116, 2552.

[253] Boerrigter, G.; Costello-Boerrigter, L.C.; Cataliotti, A.; Lapp, H.; Stasch, J.; Burnett, J.C.Jr Hypertension, 2007, 49, 1128.

[254] Lapp, H.; Mitrovic, V.; Franz, N.; Heuer, H.; Buerke, M.; Wolfertz, J.; Mück, W.; Unger, S.; Wensing, G.; Frey, R. BMC Pharmacology, 2007, 7, S9.

[255] Schindler, U.; Strobel, H.; Schönafinger, K.; Linz, W.; Löhn, M.; Martorana, P.A.; Rütten, H.; Schindler, P.W.; Busch, A.E.; Sohn, M.; Töpfer, A.; Pistorius, A.; Jannek, C.; Mülsch, A. Mol. Pharmacol., 2006, 69, 1260.

[256] van Eickels, M.; Wassmann, S.; Schäfer, A.; Bauersachs, J.;

Strobel, H.; Rütten, H. BMC Pharmacology, 2007, 7, S4.

[257] Schindler, U.; Klein, M.; Linz, W.; Rütten, H.; Schäfer, S.; Strobel, H.; Schäfer, A.; Bauersachs, J.; Wassmann, S.; van Eickels, M. BMC Pharmacology, 2005, 5, S19. 
[258] Schäfer, A.; Flierl, U.; Kobsar, A.; Eigenthaler, M.; Ertl, G.; Bauersachs, J. Arterioscler. Thromb. Vasc. Biol., 2006, 26, 2813.

[259] Cobb, J.P. Surg. Infect. (Larchmt)., 2003, 2, 93.

[260] Harbrecht, B.G. Curr. Pharm. Des., 2006, 12, 3543.

[261] Jaffe, E.R.; Neurmann, G. Nature, 1964, 202, 607.

[262] Martínez Portillo, F.; Hoang-Boehm, J.; Weiss, J.; Alken, P.; Jünemann, K. Eur. Urol., 2001, 39, 20.

[263] Gruetter, C.A.; Barry, B.K.; McNamara, D.B.; Gruetter, D.Y.; Kadowitz, P.J.; Ignarro, L. J. Cyclic. Nucleotide. Res., 1979, 5, 211.

[264] Mülsch, A.; Busse, R.; Liebau, S.; Förstermann, U. J. Pharmacol. Exp. Ther., 1988, 247, 283.

[265] Luo, D.; Das, S.; Vincent, S.R. Eur. J. Pharmacol., 1995, 290, 247.

[266] Mayer, B.; Brunner, F.; Schmidt, K. Eur. Heart J., 1993, 14 Suppl I, 22.

[267] Mayer, B.; Brunner, F.; Schmidt, K. Biochem. Pharmacol., $1993,45,367$.

[268] Kumagai, Y.; Midorikawa, K.; Nakai, Y.; Yoshikawa, T.;

Kushida, K.; Homma-Takeda, S.; Shimojo, N. Eur. J.

Pharmacol., 1998, 360, 213.

[269] Stockand, J.D.; Sansom, S.C. Biochim. Biophys. Acta, 1996, $1285,123$.

[270] Buzato, M.A.S.; Viaro, F.; Piccinato, C.E.; Evora, P.R.B.

Shock, 2005, 23, 582 .

[271] Evora, P.R.B.; Viaro, F. Curr. Drug Targets., 2006, 7, 1195. 
[272] Kwok, E.S.H.; Howes, D. J. Intensive. Care Med., 2006, 21, 359.

[273] Feelisch, M.; Kotsonis, P.; Siebe, J.; Clement, B.; Schmidt, H.H. Mol. Pharmacol., 1999, 56, 243.

[274] Zingarelli, B.; Haskó, G.; Salzman, A.L.; Szabó, C. Crit. Care Med., 1999, 27, 1701.

[275] Severina, I.S.; Bussygina, O.G.; Pyatakova, N.V. Biochemistry (Mosc)., 2000, 65, 783.

[276] Severina, I.S.; Pyatakova, N.V.; Postnikov, A.B.;

Preobrazhenskaya, M.N.; Khropov, Y.V. Eur. J. Pharmacol., 2004, 483, 127.

[277] Severina, I.S.; Pyatakova, N.V.; Bussygina, O.G.;

Mikhailitsyn, F.S.; Khropov, Y.V. Eur. J. Pharmacol., 2002, 438, 69 .

[278] Severina, I.S.; Bussygina, O.G.; Pyatakova, N.V.; Khropov, Y.V.; Krasnoperov, R.A. Eur. J. Pharmacol., 2000, 407, 61.

[279] Holécyová, A.; Kriska, M. Bratisl. Lek. Listy., 1998, 99, 99.

[280] Mingone, C.J.; Gupte, S.A.; Chow, J.L.; Ahmad, M.; Abraham, N.G.; Wolin, M.S. Am. J. Physiol. Lung Cell Mol. Physiol., 2006, 291, L337.

[281] McLaughlin, B.E.; Chretien, M.L.; Choi, C.; Brien, J.F.;

Nakatsu, K.; Marks, G.S. Can. J. Physiol. Pharmacol., 2000, $78,343$.

[282] Gong, G.X.; Weiss, H.R.; Tse, J.; Scholz, P.M. Eur. J.

Pharmacol., 1998, 344, 299.

[283] Suzuki, T.; Suematsu, M.; Makino, R. FEBS Lett., 2001, 507, 49. 
[284] Koglin, M.; Behrends, S. Biochem. Pharmacol., 2002, 64, 109.

[285] Venema, R.C.; Venema, V.J.; Ju, H.; Harris, M.B.; Snead, C.; Jilling, T.; Dimitropoulou, C.; Maragoudakis, M.E.; Catravas, J.D. Am. J. Physiol. Heart Circ. Physiol., 2003, 285, H669.

[286] Balashova, N.; Chang, F.; Lamothe, M.; Sun, Q.; Beuve, A. J. Biol. Chem., 2005, 280, 2186.

[287] Hanafy, K.A.; Martin, E.; Murad, F. J. Biol. Chem., 2004, 279, 46946. 